\title{
High-resolution paleolimnology opens new management perspectives for lakes adaptation to climate warming
}

OPEN ACCESS

Edited by:

Isabelle Larocque-Tobler,

The L.A.K.E.S. Institute, Switzerland

Reviewed by:

Mariusz Lamentowicz,

Adam Mickiewicz University in

Poznan, Poland

Tomi P. Luoto,

University of Helsinki, Finland

*Correspondence:

Marie-Elodie Perga,

UMR CARRTEL, 75 Avenue de

Corzent, 74203 Thonon les Bains

Cedex, France

marie-elodie.perga@thonon.inra.fr

Specialty section:

This article was submitted to

Paleoecology,

a section of the journal

Frontiers in Ecology and Evolution

Received: 30 March 2015

Accepted: 23 June 2015

Published: 07 July 2015

Citation:

Perga M-E, Frossard V, Jenny J-P, Alric B, Arnaud F, Berthon V, Black JL, Domaizon I, Giguet-Covex C, Kirkham A, Magny M, Manca M, Marchetto A, Millet $L$, Paillès $C$, Pignol $C$, Poulenard

$J$, Reyss J-L, Rimet F, Sabatier P,

Savichtcheva $O$, Sylvestre $F$ and

Verneaux V (2015) High-resolution

paleolimnology opens new

management perspectives for lakes adaptation to climate warming.

Front. Ecol. Evol. 3:72.

doi: 10.3389/fevo.2015.00072

\begin{abstract}
Marie-Elodie Perga ${ }^{1 *}$, Victor Frossard ${ }^{2,3}$, Jean-Philippe Jenny 1, 4,5,6, Benjamin Alric ${ }^{1}$, Fabien Arnaud ${ }^{4}$, Vincent Berthon ${ }^{1}$, Jessica L. Black ${ }^{7}$, Isabelle Domaizon ${ }^{1}$, Charline Giguet-Covex ${ }^{4}$, Amy Kirkham ${ }^{1}$, Michel Magny ${ }^{3}$, Marina Manca ${ }^{8}$, Aldo Marchetto ${ }^{8}$, Laurent Millet ${ }^{3}$, Christine Paillès ${ }^{7}$, Cecile Pignol ${ }^{4}$, Jérome Poulenard ${ }^{4}$, Jean-Louis Reyss ${ }^{4}$, Frederic Rimet ${ }^{1}$, Pierre Sabatier ${ }^{4}$, Olga Savichtcheva ${ }^{1}$, Florence Sylvestre $^{7}$ and Valérie Verneaux ${ }^{3}$

${ }^{1}$ INRA, UMR CARRTEL, Université Savoie-Mont-Blanc, Thonon les Bains, France, ${ }^{2}$ UMR CARRTEL, University of Savoie-Mont Blanc, Chambéry, France, ${ }^{3}$ UMR Chrono-Environnement, Besaçon, France, ${ }^{4}$ Environnements, Dynamiques et Territoires de la Montagne, University of Savoie-Mont Blanc, Chambéry, France, ${ }^{5}$ Centre Eau Terre Environnement, Institut National de la Recherche Scientifique, Québec, QC, Canada, ${ }^{6}$ Geochemistry and Geodynamics Research Center (GEOTOP), Montreal, QC, Canada, ${ }^{7}$ Centre National de la Recherche Scientifique, Aix-Marseille Université, Institut de Recherche pour le Développement, UM34 Centre Européen de Recherche et d'Enseignement des Géosciences de l'Environnement, Aix en Provence, France, ${ }^{8}$ Consiglio Nazionale delle Ricerche-Istituto per lo Studio degli Ecosistemi, Verbania-Pallanza, Italy, ${ }^{9}$ Le Laboratoire des Sciences du Climat et de l'Environnement, Gif-sur-Yvette, France
\end{abstract}

Varved lake sediments provide opportunities for high-resolution paleolimnological investigations that may extend monitoring surveys in order to target priority management actions under climate warming. This paper provides the synthesis of an international research program relying on >150 years-long, varved records for three managed perialpine lakes in Europe (Lakes Geneva, Annecy, and Bourget). The dynamics of the dominant, local human pressures, as well as the ecological responses in the pelagic, benthic, and littoral habitats were reconstructed using classical and newly developed paleo-proxies. Statistical modeling achieved the hierarchization of the drivers of their ecological trajectories. All three lakes underwent different levels of eutrophication in the first half of the XXth century, followed by re-oligotrophication. Climate warming came along with a $2^{\circ} \mathrm{C}$ increase in air temperature over the last century, to which lakes were unequally thermally vulnerable. Unsurprisingly, phosphorous concentration has been the dominant ecological driver over the last century. Yet, other human-influenced, local environmental drivers (fisheries management practices, river regulations) have also significantly inflected ecological trajectories. Climate change has been impacting all habitats at rates that, in some cases, exceeded those of local factors. The amplitude and ecological responses to similar climate change varied between lakes, but, at least for pelagic habitats, rather depended on the intensity of local human pressures than on the thermal effect of climate change. Deep habitats yet showed higher sensitivity to climate change but substantial influence of river flows. As a consequence, adapted local management strategies, fully integrating nutrient inputs, fisheries management, and hydrological regulations, may enable mitigating the deleterious consequences of ongoing climate change on these ecosystems.

Keywords: vulnerability, mitigation, lakes, varve sediments, climate change, management 


\section{Introduction}

Lake ecological states and services are compromised by the multiple local human activities they host, and by the complex effects of climate change. Targeting priority management actions requires deciphering which of these environmental pressures are actually responsible for deleterious ecological alterations, while current policies and practices, designed to improve the ecological status of freshwater ecosystems, need to be modified in light of projected future climate change (ter Heerdt et al., 2007; Ulen and Weyhenmeyer, 2007; Reyjol et al., 2014). Such purposes imply that we can assess how current and future climate inflects lake ecological trajectories.

The question of the consequences of climate change on lakes has been intensively tackled over the last decade (Kernan et al., 2010; Dokulil, 2014 for syntheses), with a dominant focus on the detection of common trends by which lakes respond physically, chemically, and biologically to atmospheric warming. Indeed, many of the lake physical responses (increase in surface water temperature, stratification length, timing of ice out) are vertically and spatially coherent across large geographical distances (Livingstone and Dokulil, 2001; Dokulil et al., 2006; Livingstone et al., 2010) while the amplitude of the actual effects shall vary according to geomorphological parameters, such as altitude, shading, surface area, and depth (Fee et al., 1996; Livingstone and Padisak, 2007; Dokulil, 2014). Regional coherence in the lake chemical responses to climate change is somewhat lower (Dokulil and Teubner, 2002; Livingstone et al., 2010) as chemical consequences of climate variability ( $\mathrm{pH}$, nutrient concentrations, oxygenation) are modulated by the catchment geological and hydrological characteristics (Schindler et al., 1996; Webster et al., 1996; Blenckner, 2005). For biological parameters, climate change triggers complex cause-effects chains (Shurin et al., 2012), the link between them provided by many interacting parameters that already responded individually to climate change (Woodward et al., 2010). Even though some common biological features have been observed between lakes (Smol et al., 2005; Burgmer et al., 2007), climate-induced changes of the lake biota remain highly idiosyncratic even for lakes within the same catchment (De Stasio et al., 1996; Dokulil, 2014). Overall, biological responses to climate change are less predictable than the response of chemical or hydrological variables (Hering et al., 2010). Even within a single lake, climateinduced changes in water temperature, and in turn in chemical parameters, might not be as pronounced between deep and surface waters, or even occur in opposite directions at different depths (Magnuson et al., 1997; Danis et al., 2004). Therefore the magnitude of the biotic responses to climate change might also be highly variable according to different habitats (surface, deep, or littoral areas). Such uncertainties on lake biodiversity responses to climate change obviously limit forecasting the future of lake ecosystem services (Reyjol et al., 2014).

Although considerable progress has been made in understanding lakes responses to climate change, long-term ecological changes within anthropogenized lakes are probably those for which knowledge is lacking the most. For those systems that have been, and still are, strongly influenced in other ways by human activities over recent decades and last centuries, it is doubly difficult, although vital, to hierarchize the actual contribution of climate change as compared to other, more local, environmental stressors (Leavitt et al., 2009). For instance, nutrient inputs to lakes, from single point or atmospheric sources, and climate change, have evolved synchronously over the last century. Their respective contributions on lake functioning is hardly discernable since both can trigger increasing lake productivity by direct effects on the length of the growing season or indirect effects by altering the bottom-up and top-down control of the food web structure (Jeppesen et al., 2005). The parallel temporal dynamics of human perturbations make difficult to unravel the individual effect of each one in generating eutrophication symptoms (Wolfe et al., 2001; Jeppesen et al., 2005) and the mechanistic pathways by which they act. Instrumental data-series are usually too short to deal with so many degrees of freedom and to attribute unambiguously observed changes to any local and/or climate factors (Leavitt et al., 2009). In addition, lake ecological responses to climate change are so context-dependent that conclusions holding for one lake that has benefited from long-term monitoring can hardly be extrapolated to its neighbor (Dokulil, 2014). Controlled experiments have proven successful in distinguishing interacting effects between nutrient inputs and water warming (Moss et al., 2003; Shurin et al., 2012). Their outcomes suggest, for instance, that controlling nutrient inputs to lakes could help mitigating the impact of climate change (Battarbee, 2010). Yet, they relied on simple systems that necessarily minimize interactive mechanisms occurring at larger temporal and spatial scale. The realism and relevancy of the mechanisms hindcast by such controlled experiment have then to be confronted to longterm observational data (Battarbee, 2010). Paleo-records have provided compelling evidence that current climate conditions have triggered unprecedent ecological changes in high latitudes or altitudes lakes, i.e., ecosystems remote from direct human disturbances (Battarbee, 2010). Yet, for most other freshwaters ecosystems situated in populated regions, the risk of circular reasoning (sensu Battarbee, 2010) and the low accuracy and temporal resolution of the sediment records at sub-decadal time scales limit the possibility of disentangling the consequences of climate change from those of local human activities (Battarbee, 2010).

An international research program (which acronym was IPER-RETRO) has been conducted between 2009 and 2013 to precisely tackle the question of the ecological vulnerability of temperate lakes within populated catchments to climate change (i.e., how and how much they have been responding to climate change), for which this paper provides a synthesis of the main outputs. IPER-RETRO relied on the three following hypotheses:

1. Climate warming has overpassed local human activities in driving the ecological trajectories of lakes; i.e., lakes within populated watersheds are vulnerable to climate change.

2. Because of interactions between local human activities and climate warming, lakes ecological responses to a similar climate variability depend on the intensity of the local forcings: 
lake vulnerability to climate change is conditioned by local forcings.

3. Lake habitats are not equally vulnerable to climate warming.

Overall, the findings of this research can help providing new perspectives for lake managers (stakeholders) to preserve and orientate lakes ecological trajectories under climate change and promote ecosystem services.

\section{General Rationale}

The program was designed in order to evaluate how variations in the intensity of local forcings can affect lake responses to similar climate variability, by comparing the ecological trajectories of different lake habitats for three lakes (Geneva, Annecy, and Bourget, Figure 1).

These three subalpine lakes have been carved by the same glacial-tectonic processes 12,000 years ago from which they inherited a comparable geomorphology of large, deep and Ushaped basins as well as a similar geochemical calcareous substratum. All located within $70 \mathrm{~km}$ from each other at a similar altitude, they are submitted to a comparable climate variability for which long-term local meteorological records were available (HISTALP, Auer et al., 2007). Otherwise, it was expected that geomorphological similarities minimize differences in their thermal responses to climate change. They also share a common human history over the last 150 years and therefore endured a similar combination of local forcings over time, yet at different intensities. The human population density has increased 3- to 5fold from the late XIX $^{\text {th }}$ century and has triggered eutrophication from the 1930's to the mid-1970's. Maximum Total Phosphorus concentrations (TP) yet differed between lakes but phosphorus inputs from their watersheds have then been successfully abated in the second half of the $\mathrm{XX}^{\text {th }}$ century and onwards. They host similar fish communities that are yet managed according to slightly different management strategies (Alric et al., 2013).

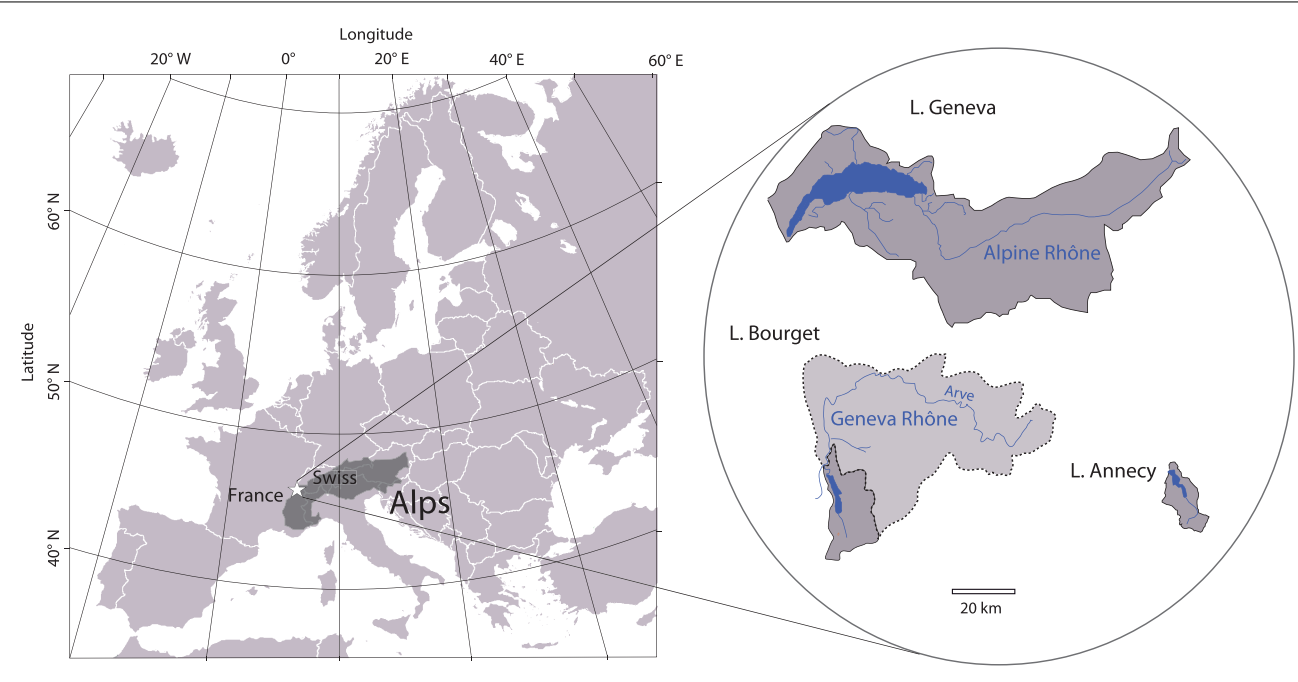

\begin{tabular}{|c|c|c|c|}
\hline Parameters & Lake Annecy & Lake Geneva & Lake Bourget \\
\hline Maximum depth $(\mathrm{m})$ & 65 & 309 & 147 \\
\hline Total lake area $\left(\mathbf{k m}^{2}\right)$ & 27 & 582 & 45 \\
\hline Drainage basin area $\left(\mathrm{km}^{2}\right)$ & 273 & 7395 & 560 \\
\hline $\begin{array}{l}\text { Drainage basin area to the } \\
\text { total lake area }\end{array}$ & 10.1 & 12.7 & 12.4 \\
\hline Volume $\left(\mathrm{km}^{3}\right)$ & 1.12 & 89 & 3.6 \\
\hline $\begin{array}{l}\text { River discharge (outlet, } \\
\mathrm{m}^{3} \cdot \mathrm{s}^{-1} \text { ) }\end{array}$ & 8 & 244 & $\begin{array}{c}15(+30-40 \\
\text { days.yr }{ }^{-1} \text { of } \\
\text { flow inversion) }\end{array}$ \\
\hline Renewal rate (yr) & 4 & 12 & 8 \\
\hline
\end{tabular}

FIGURE 1 | Lakes location and geomorphological characteristics. 
The initial hydrology of their watershed and additional human activities resulted in different flood frequencies for each lake (Jenny et al., 2014a,b). They have been routinely monitored over decadal (Annecy, Bourget) or pluri-decadal time scales (Geneva, Table 1). In addition, all three lakes have annually laminated sediments (Jenny et al., 2014a), therefore allowing high-resolution dating (annual up to tri-annual time-steps that were relevant for ecological purposes) and confident correlation between multiple and spatially distributed cores within a single lake (about 150 cores per lake and up to 3000 dated samples; see Jenny et al. (2014a) for methodological details).

All these lakes characteristics promoted a process-oriented comparative design in which annually-dated paleo-records and long-term monitoring data were combined to reconstruct, over two centuries, (i) the dynamics of climate (monitoring data) and local forcings (TP, fisheries management practices, and river discharge; paleo-records calibrated against available monitoring data) and (ii) the multiple biotic (diatoms, cladocerans, cyanobacteria, chironomids) and geochemical (hypoxia, carbon cycling) changes occurring in the pelagic, benthic and littoral habitats (paleo-records). Such reconstructions for local forcings and responses were based on classical and/or newly developed paleo-proxies (Table 1). Finally, the respective contribution of climate change vs. local forcings in driving observed ecological changes, such as the time-period at which they contributed to these changes, could be hierarchized, based on Generalized additive models (GAM, Simpson and Anderson, 2009).

TABLE 1 | Summary of neo- and palaeo-ecological data used to infer the dynamics of climate and local forcings and ecological trajectories of lakes Geneva, Annecy, and Bourget over the last 200 years.

\begin{tabular}{|c|c|c|c|}
\hline \multicolumn{2}{|c|}{ Environmental forcings } & \multirow[t]{3}{*}{ Paleo-proxy } & \multirow{2}{*}{$\begin{array}{l}\text { Available monitoring data } \\
\text { HISTALP (1850-2007) }\end{array}$} \\
\hline Climate & Air temperatures & & \\
\hline & & & Météo-France (1960) \\
\hline \multirow[t]{3}{*}{$\begin{array}{l}\text { Local human } \\
\text { forcings }\end{array}$} & $\begin{array}{l}\text { Lake TP concentrations (annual averages over 0-20 m } \\
\text { depths) }\end{array}$ & $\begin{array}{l}\text { Diatom-inferred TP (Berthon et al., 2013) } \\
\text { Daphnia-inferred TP* (Berthon et al., 2014) }\end{array}$ & $\begin{array}{l}\text { Geneva (1958-2010) } \\
\text { Annecy }(1969-1981 ; 1992-) \\
\text { Bourget }(1970-1972 ; 2003-)\end{array}$ \\
\hline & $\begin{array}{l}\text { Management-induced predation pressure on } \\
\text { zooplankton }\end{array}$ & $\begin{array}{l}\text { Size of Daphnia post-abdominal claws* (Alric } \\
\text { et al., 2013) }\end{array}$ & $\begin{array}{l}\text { Zooplanktivorous fish catches } \\
\text { Geneva (1900-) } \\
\text { Annecy (1967-) } \\
\text { Bourget (1920-) }\end{array}$ \\
\hline & $\begin{array}{l}\text { Volumes and frequencies of floods from dominant } \\
\text { tributaries }\end{array}$ & $\begin{array}{l}\text { Flux of terrigenous elements (Jenny et al., } \\
\text { 2014a) } \\
\text { 3D distribution of flood event deposits (Jenny } \\
\text { et al., 2014b) }\end{array}$ & $\begin{array}{l}\frac{\text { Geneva (1800-2010) }}{\text { Annecy }(1800-2010)} \\
\text { Bourget (1800-2010) } \\
\text { Bourget (1700-2010) }\end{array}$ \\
\hline
\end{tabular}

Ecological lake trajectories

Paleo-proxy

Available monitoring data

Community

structures
Planktonic diatoms

Cladocerans

Total cyanobacteria and Planktothrix abundances and taxonomic composition

Pico-cyanobacteria abundances and taxonomic composition

Littoral and benthic chironomids

Daphnia gene flow

Carbon cycling

Hypoxic volumes
Diatoms macro-fossil remains (Berthon et al., 2013, 2014)

Cladoceran macro-fossil remains (Alric and Perga, 2011; Alric et al., 2013)

Q-PCR \& Sequencing ${ }^{*}$ on 16SrRNA gene +ITS; mcyA gene; Phycocyanine operon (Savichtcheva et al., 2011, 2014)

Geneva (1977-)

Geneva (1977-)

Bourget (2000-2010)

Geneva (1977-) Annecy (1992-)

Q-PCR Sequencing* on 16SrRNA gene +ITS (Domaizon et al., 2013)

Spatially structured chironomid assemblages (Frossard et al., 2013, 2014)

Micro-satelitte analyses of Daphnia resting eggs (Alric, 2012)

Geochemistry

$\delta^{13} \mathrm{C}$ of sub-fossil remains (Perga, 2010, 2011; Frossard et al., 2014, 2015)

3D Distribution of laminated sediments (Jenny et al., 2013, 2014a)*
Geneva (1958-)

*Pinpoints paleo-proxies that were newly developed and validated within the program. Underlined data were provided by $\odot$ SOERE OLA-IS, INRA Thonon-les-Bains, CISALB, CIPEL, SILA, [02-02-2014], developed by Eco-Informatics ORE INRA Team. 


\section{Environmental Context}

\section{Lakes Location and Hydrology}

Lakes Geneva, Bourget, and Annecy are young lakes originating from the last deglaciation, located on the northwest edge of the French Alps (Figure 1). They belong to a similar hydro-ecoregion. They are large, deep temperate lakes (i.e., free from ice during winter) with a relatively fast water renewal rate (Table 1).

However, the three lakes present contrasting hydrological conditions because water and sediment supplies from the river systems differ greatly among the three lakes. The supplies are the highest from the large "Alpine-Rhône," with a mean annual discharge of $181 \mathrm{~m}^{3} \mathrm{~s}^{-1}$, which flows directly into Lake Geneva. These supplies are lower from the "Geneva-Rhône," downstream of Lake Geneva, which flows at a rate of from 10 to $100 \mathrm{~m}^{3}$ $\mathrm{s}^{-1}$ and discharges into Lake Bourget through the Savière Channel only during major flooding events (Giguet-Covex et al., 2010). Lake Annecy is only supplied by small local tributaries. Hydrological differences between lakes are well mirrored by outlet flows and the ratio of the drainage basin area to the total lake area (Meybeck, 1995) confirmed the differences in the local river inputs for the three lakes (Figure 1).

\section{The Dynamics of Climate and Local Forcings over the Last 150 Years}

\section{Climate Warming and Physical Responses from the Water Column}

Consistently to the trends observed for the Greater perialpine region (Beniston, 2006), air temperature over the three studied lakes has increased stepwise by almost $2.0^{\circ} \mathrm{C}$ during the XXth century (Figure 2A), with a first warming period between 1940 and 1960 and a second one in the early 1980s (Auer et al., 2007; Alric et al., 2013). Comparison of the data extracted from HISTALP to local meteorological monitoring (Meteo-France 1960-2008) confirmed they adequately captured the interannual variability and trends in air temperatures. This pronounced temperature increase is due to the well-documented northward shift of the subtropical high-pressure system (Auer et al., 2007). Since no trend was observed for mean annual precipitation on the three lakes (Figure 2A), only mean air temperature was used in the following and we therefore refer as to "climate warming."

Water temperature monitoring (Table 1; Data (C) SOERE OLA-IS, INRA Thonon-les-Bains, CISALB, CIPEL, SILA, developed by Eco-Informatics ORE INRA Team) covered $>30$

\section{A CLIMATE DATA}
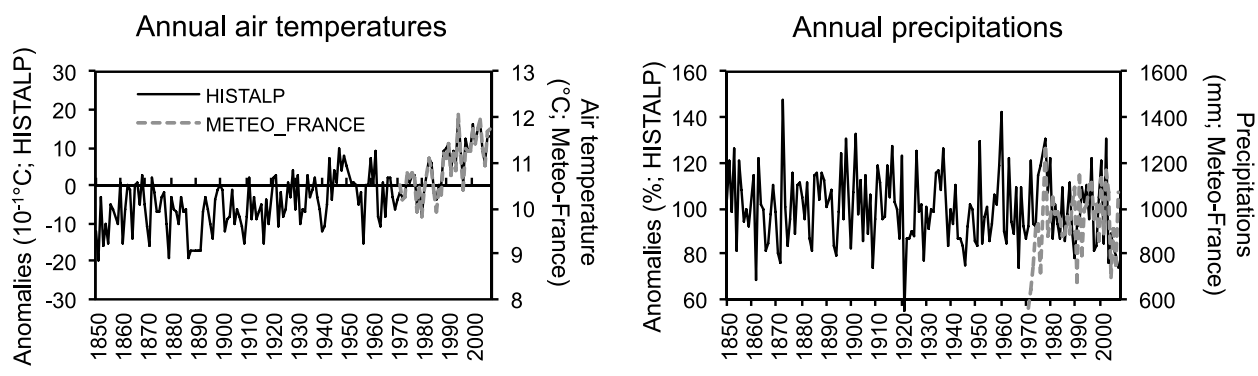

B LAKES THERMAL RESPONSES

L. ANNECY
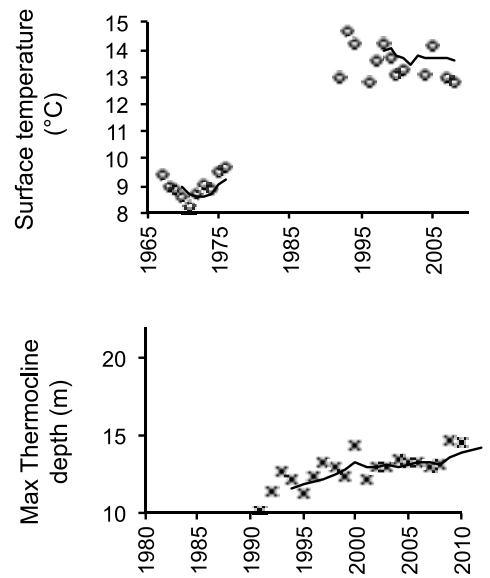

L. GENEVA

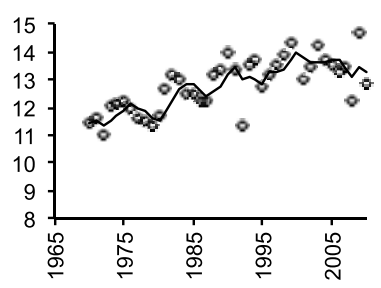

L. BOURGET
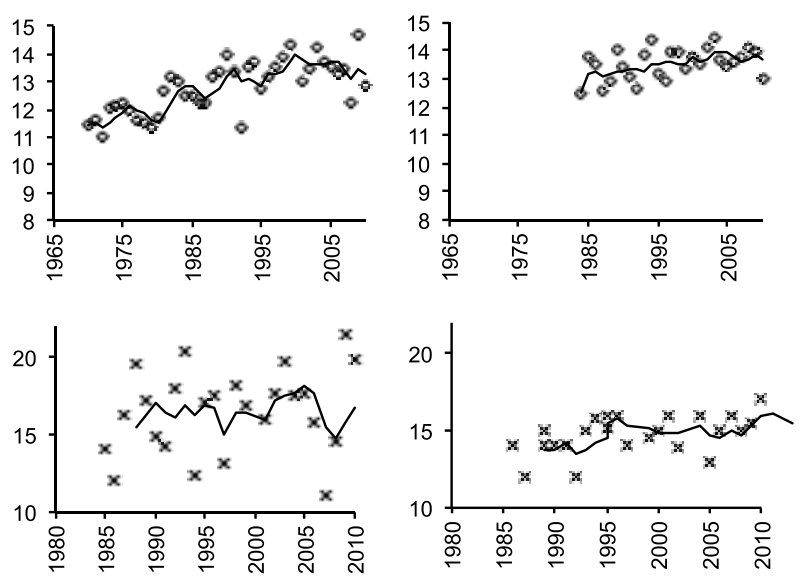

FIGURE 2 | (A) Climate variability over the three lakes for the last 150 years as extrapolated from HISTALP and comparison to locally monitored data (Meteo-France). (B) Changes lake key thermal characteristics, upper panel: average lake surface temperature over 0-15 m depths; lower panel: maximum depth of the $14^{\circ} \mathrm{C}$ layer, as a surrogate for late summer thermocline. Lines represent 5 -year moving averages. 
years for Lake Annecy (1966-1975 and >1996) and Geneva $(>1970)$ and revealed that the surface temperatures $(0-15 \mathrm{~m}$ depths) of these two lakes significantly increased between 19701975 and 2007-2012 (Lake Annecy, Mann Kendall's $\tau=0.47$, $p=2.10^{-11}$; Lake Geneva; Mann Kendall's $\tau=0.59, p=$ $1.10^{-4}$; Figure 2B). Lake Annecy surface temperatures increased more than those of Lake Geneva between these two periods $\left(+3.5^{\circ} \mathrm{C}\right.$ for Lake Annecy, $+1.1^{\circ} \mathrm{C}$ for Lake Geneva). Continuous monitoring of Lake Geneva since 1970 revealed that surface temperature warmed suddenly at the end of 1980 (Anneville et al., 2013). However, despite a continuous increase in air temperature, surface temperature did not warm further up over the last 20 years in any of the three lakes (Lake Geneva $\tau=0.28 ; p=0.11$; Lake Annecy $\tau=0.12 ; p=0.66$; Lake Bourget $\tau=0.05$; $p=0.77$ ). Between the mid 1980s and the current period, Lake Bourget surface water temperature increased less $\left(+0.8^{\circ} \mathrm{C} ; t=\right.$ 1.8; $p=0.13)$ than those of Lake Geneva $\left(+1.4^{\circ} \mathrm{C} ; t=2.8\right.$; $p=0.03)$ over the same period. Data analyses and modeling studies confirmed that stratification duration has increased in all three lakes (Danis et al., 2004; Vincon-Leite et al., 2014; Tapolczai et al., 2015). The thermocline has deepened by $2.5 \mathrm{~m}$ in Lake Annecy and by $1.5 \mathrm{~m}$ in Lake Bourget (Annecy: Mann Kendall's $\tau=0.61, p=9.10^{-5}$, Bourget: $\tau=0.32, p=0.02$ ) over the last 20 years but stayed at similar depth for Lake Geneva (Mann Kendall's $\tau=0.18, p=0.21$; Figure 2B).

In summary, despite their similar geomorphology and geographical proximity, the three studied lakes are not equally thermally vulnerable to climate change. Lake Annecy is the smallest of the three lakes, the most sheltered from winds and the least hydrologically active. Consistently, it is the one for which the thermal effects of climate warming are the strongest (warming of surface waters, thermocline deepening). In lakes Geneva and Bourget, the thermal effects are weaker, with however different physical consequences. In Lake Geneva, surface waters warmed up more than in Lake Bourget, the stratification length increased but with no deepening of the thermocline, in contrast to Lake Bourget (Figure 2B).

\section{Climate and Human Alterations of River Discharges}

Jenny et al. (2014a) reconstructed the inter-annual changes in river discharge from the main tributaries using terrigenous supplies, (i.e., the detrital inputs from the watershed). Since 1880, terrigenous fluxes have decreased by 50,40 , and $45 \%$ for lakes Geneva, Bourget, and Annecy, respectively, indicating a general trend to the decrease in the river discharge regime over the entire studied period (Figure 3A). This first order decrease was attributed to local river settlements, i.e., with the introduction of the first dam settlements in 1915, 1901, and 1874 in Lake Geneva, Bourget and Annecy. Despite the absence of any monotonic trend in precipitation change over the last 150 years (Figure 2), precipitations presented variations over that period at pluriannual scales. The second order fluctuations of flood regime were not directly correlated to human activities, and instead attributed to these pluri-annual variations in precipitation regime changes. Recent increases in flood regime were recorded in the 1980s in Lake Bourget and in the early 1990s and the early 2000s in Lake Geneva (Figure 3A).

\section{Changes in Nutrient Concentrations}

All the three lakes underwent eutrophication in the mid-XXth century, and even for Lake Geneva for which a long-term TP monitoring was available, the temporal dynamics of the early or later eutrophication remained unknown. Therefore, two independent transfer-functions (Diatom-inferred TP; Berthon et al., 2014, and Daphnia-inferred TP; Berthon et al., 2013) were applied to reconstruct the TP dynamics over the last two centuries to all three lakes. In contrast to the diatombased transfer function, which is ultimately based on species assemblages, the Daphnia-inferred transfer function relies on the changes in the absolute quantity of Daphnia remains. A strong linear relationship between the abundance of Daphnia remains (paleo-data) and measured total phosphorus concentrations for the corresponding years (monitoring data) was observed. Although the underlying mechanisms, likely depending on how much Daphnia high requirements for P constrain its growth rates (Sterner, 1993; Urabe et al., 1997), are not completely understood, such a strong relationship then permitted to build up solid Daphnia inferred total phosphorus concentrations. Inferred TP changes were highly consistent between the two transfer functions and coherent with available TP measurements. However, the Daphnia transfer function was more efficient in detecting the earliest changes in nutrient inputs to the lakes $\left(<10 \mu \mathrm{g} \mathrm{P} . \mathrm{l}^{-1}\right.$, Figure 3B). These two independent inferences were required in order to avoid circularity in the assessment of the contribution of changes in lake trophic status on diatom and cladoceran communities structures.

Although they were oligotrophic at the end of the XIXth century, all three lakes underwent phosphorous enrichment as early as the 1920s, this process intensifying during the 1940s. The three lakes reached varying levels of maximum eutrophication. Lake Annecy did not exceed the oligomesotrophic status (i.e., mean annual concentration over the first $20 \mathrm{~m}$ depths: $18 \mu \mathrm{gP} . \mathrm{l}^{-1}$ in 1969). Lakes Geneva and Bourget reached a eutrophic status by the late 1970s (i.e., mean annual concentration over the first $20 \mathrm{~m}$ depths: 55-90 $\mu \mathrm{g} \mathrm{P.} \mathrm{l}^{-1}$ ). Following restoration programs during the past three decades, observational data demonstrate that mean TP measured during winter mixing have been successfully reduced to $6 \mu \mathrm{g} \mathrm{P} .1^{-1}$ in Annecy, $19 \mu \mathrm{g} \mathrm{P} .1^{-1}$ in Geneva and $17 \mu \mathrm{g}$ P. $1^{-1}$ in Bourget (Berthon et al., 2013; Figure 3B).

\section{Changes in Fish Management Practices}

Fish communities in the three study lakes are similar and typical of subalpine lakes with autochthonous or early-introduced whitefish (Coregonus lavaretus), perch (Perca fluviatilis), roach (Rutilus rutilus), and pike (Esox luscious) as dominant species. Fish communities were also altered through fisheries management practices. Different strategies in the stocking stages of whitefish as well as different authorized fishing size for perch juveniles (YOY) have created varying fish predation pressures over the last 30 years. The dynamics over time in the top-down control of fish on zooplankton were tracked in the sediment from the changing size of Daphnia claws over time following the size efficiency hypothesis (Alric et al., 2013). In all three lakes, and consistently with regulation patterns of bottom-up and top-down controls on food webs, fish predation pressure was low under 
L. ANNECY
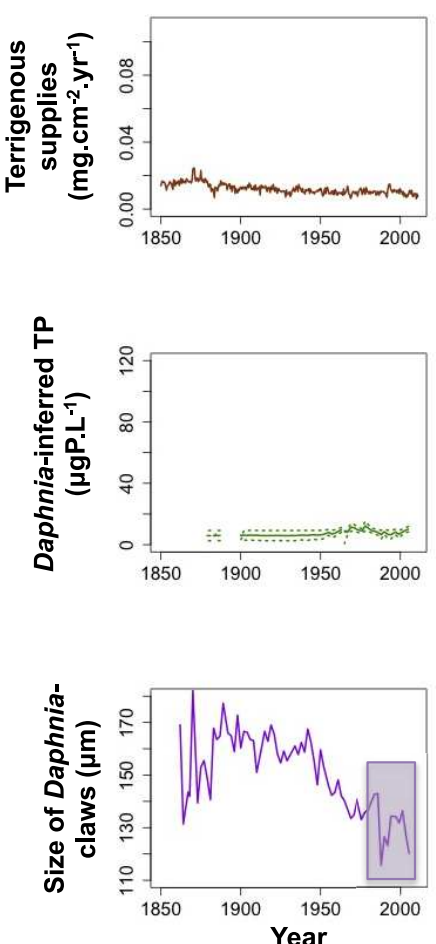

L. GENEVA

A RIVER DISCHARGE

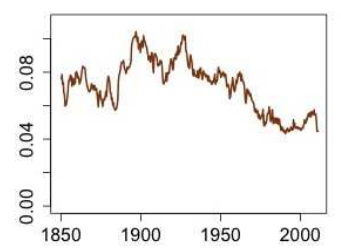

B NUTRIENT INPUTS
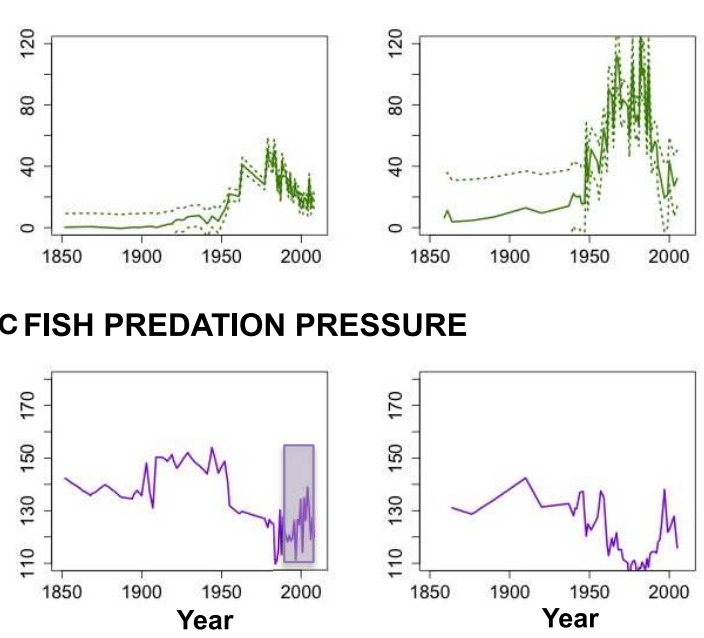

L. BOURGET

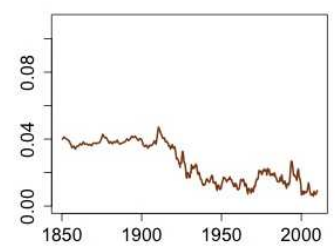

\section{CFISH PREDATION PRESSURE}

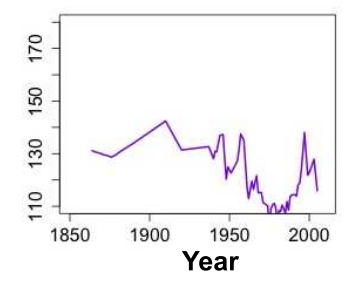

FIGURE 3 | Temporal dynamics of the local human forcings on all three lakes. (A) Terrigenous supplies as a proxy for river discharge (Jenny et al., 2014a); (B) Changes in phosphorus inputs as TP $( \pm 95 \%$ confidence interval) inferred from the abundance of Daphnia remains

(Berthon et al., 2014); results were highly similar for diatom-inferred TP;
(C) Changes in fish predation pressure on zooplankton, as inferred from temporal changes in the size of Daphnia (Alric et al., 2013). Changes in fish predation pressure that are decoupled from TP (purple rectangles) are considered as resulting from specific fisheries management practices in Lakes Annecy and Geneva. oligotrophic conditions (and therefore, Daphnia were large) but increased during eutrophication. Reversible trajectories (decline in fish predation pressure during re-oligotrophication, mirrored by greater Daphnia body sizes) were however observed only in Lake Bourget. In this lake, fish predation pressure is fully coupled to TP, and local fisheries management practices preserve the top-down/bottom-up coupling (Figure 3). For the other two lakes, fisheries management practices (whitefish stocking at early stages and interdiction of fishing on Perch YOY) increased fish predation pressure on zooplankton and have disrupted the bottom-up/top-down controls. Fish predation pressure has remained high (Geneva) or even increased (Annecy) over the last 30 years (Alric et al., 2013; Figure 3C).

\section{The Vulnerability of the Different Lake Habitats to Climate Warming}

\section{Plankton Components and Considered Metrics}

"Plankton" designates a vast, diverse, and heterogeneous biological assemblage. It would not have been possible to address the total planktonic biodiversity over time in these three lakes, even relying on molecular methods, as the final purpose was to functionally relate community changes to climate warming. Instead, we targeted key-functional components, representative for biological diversity within plankton. We intended to cover both protozoans and metazoan organisms, from different positions in the food web (primary producers and secondary, tertiary consumers through cladocerans), from pico-(Synechococcus), to nano- and micro-plankton (large cyanobacteria and diatoms). Depending on available or developed methods, changes were quantified in term of taxonomic presence/absence (cloning sequencing on specific targets such as for pico-cyanobacteria or diatoms); species relative distribution (microscope countings of remains for diatoms and cladocerans) or abundance (quantitative PCR for total cyanobacteria or Planktothryx rubescens).

\section{Climate Warming Impacts on Phytoplankton Communities at Pico-, Nano-, and Micro-planktonic Scales Diatoms}

Fossil remains of diatoms are inescapable paleo-descriptors, and they were used to infer several lake physical and chemical characteristics. Their use as indicator of past temperature 
is, however, more complex, because physical, chemical, and biological factors can affect diatom assemblage composition independently of water temperature (Battarbee, 2000). In fact, diatom response to climatic forcing can be strongly influenced by the characteristics of the lakes. For example, the comparison of the numerous available diatom paleo-records from remote lakes have already highlighted a general trend to the expansion of Cyclotella due to climate warming (Smol et al., 2005; Rühland et al., 2008; Winder et al., 2009), as a structural consequence of their competitive ability in stratified and nutrient-poor waters (Winder et al., 2009). On the contrary, in the deep lakes around the Alps, which are well-stratified because of their morphological features and were oligotrophic for most of their history, Cyclotella was the dominant diatom genus in periods of low trophy (e.g., Marchetto and Benedetti, 1995; Marchetto et al., 2004) and its presence cannot be considered as a symptom of recent warming.

Such background knowledge offered a further opportunity to compare diatoms responses to climate warming between those lakes protected from direct human exposure and the urbanized lakes of the program. Yet, paleo-records from lakes situated in densely populated areas are scarcer, and evidence of diatom responses to climate warming was so far equivocal. Changes in nutrient concentrations usually exert such a strong contribution in shaping diatom communities over time that the climate signal is hidden or smothered (Dong et al., 2012). Appearance of so-far not observed diatom species in the uppermost part of the cores are sometimes attributed to climate warming (Thies et al., 2011; Hobæk et al., 2012). Yet, in the absence of a full consideration of potential forcings, the actual contribution of climate warming, as compared to the additional, synchronous local forcings remains uncertain, especially for such a taxonomic algal group, that, as an important grazing resource, is prompted to get also regulated by top-down controls (Perga et al., 2009). The strategic reliance on GAM, that we used all over the program, allows unlocking the methodological bolts by fully considering the temporal dynamics of local forcings (changes in TP as inferred from Daphnia abundance; fish predation pressure) and air temperature in order to quantitatively estimate when and how much each of the forcings contributed to observed changes in diatom community structure for the three studied lakes.

Consistently to previous observations of anthropogenized lakes, TP was found to be the main driver of changes in community composition over the last century, but more interestingly, was pinpointed as an important factor modulating diatom sensitivity and responses to climate warming. The slight increase in the contribution of Cyclotella in the recent decade in Lake Annecy could not be related unambiguously to warmer air temperature. Diatom communities in this nutrient-limited lake were those for which climate effect was the least detectable, although it is the one on which the physical impacts of a warmer climate are the strongest. In contrast, climate effects on diatom assemblages were much stronger in the two other, mesotrophic lakes, with yet differences in the pathways by which climate shaped their community structures (Berthon et al., 2014). The diatom community of Lake Bourget showed the highest vulnerability and direct responses to climate warming, favoring spring species that can resist earlier stratification in mesotrophic lakes (such as Asterionella formosa, Aulacoseira islandica, and Stephanodiscus parvus) and summer species that can make the best trade-off between decreasing nutrient concentrations and increased water column stability (Diatoma tenuis, A. islandica; Figure 4A). In Lake Geneva, climate warming also contributed to shaping diatom communities through an indirect pathway; fisheries management practices and climate warming interacted to reinforce top-down control, favoring large, colonial inedible species (Stephanodiscus binderanus and A. formosa) (Berthon et al., 2014). Therefore, higher nutrient concentrations seem to increase diatom vulnerability to climate warming. In addition, in the two mesotrophic lakes, observed diatom responses to climate change were more diverse suggesting that at moderate nutrient concentrations, there are more direct- and indirect pathways by which diatom life history traits (nutrient requirements, resistance to stratification, growth at low light, edibility...), and therefore species, get selected in a warmer climate.

\section{Cyanobacteria}

There are very few specific phytoplanktonic groups that have diagnostic features that are preserved upon sediment archiving (diatoms and chrysophytes), which is so far limited our understanding of long-term phytoplankton response to these micro and nano-algal communities. The recent development and application of molecular tools on DNA archived in lake sediments (Willerslev et al., 2007; Coolen et al., 2008; Boere et al., 2011; Epp et al., 2011) provide the opportunity to enlarge paleorecords to other phytoplankton groups. Herein, a privileged focus was dedicated to cyanobacteria over other taxa. The first motivation was that their proliferation jeopardizes water quality and safety but the lack of long-term data hampers the identification of the trigger of blooms, especially for toxic strains. A second one involves pico-cyanobacteria dominance within picoplankton, a size-range that has long been overlooked within biodiversity monitoring although it might play a crucial role in nutrient and carbon cycling under warmer climates. A first step involved methodological optimization, calibration, and quality control and confirmed that hypoxic and cold bottom waters of these stratified lakes favored DNA preservation, an essential pre-requisite to quantitative molecular approaches (Savichtcheva et al., 2011). Total cyanobacterial abundance over time were at first pre-screened for all three lakes using quantitative PCR (qPCR) on preserved sediment DNA. All three lakes showed temporal changes in total cyanobacterial abundances over time, that were primarily driven by meso- or eutrophic P levels. Warmer temperatures additionally favored higher cyanobacterial abundances in the two lakes that are the most thermally sensitive to climate (Annecy and Bourget; Figure 4B). In Lake Annecy through, cyanobacteria were essentially represented by picoplanktonic strains and Lake Bourget presents environmental conditions that favor a high cyanobacterial contribution to the total phytoplankton community (Jacquet et al., 2005; Savichtcheva et al., 2011).

Therefore, following paleo-genetic studies were focused on Lake Bourget. Past abundances of cyanobacteria, including picocyanobacteria (qPCR), and changes in their phylogenetic compositions [sequencing of the $16 \mathrm{~S}$ rRNA and internally 


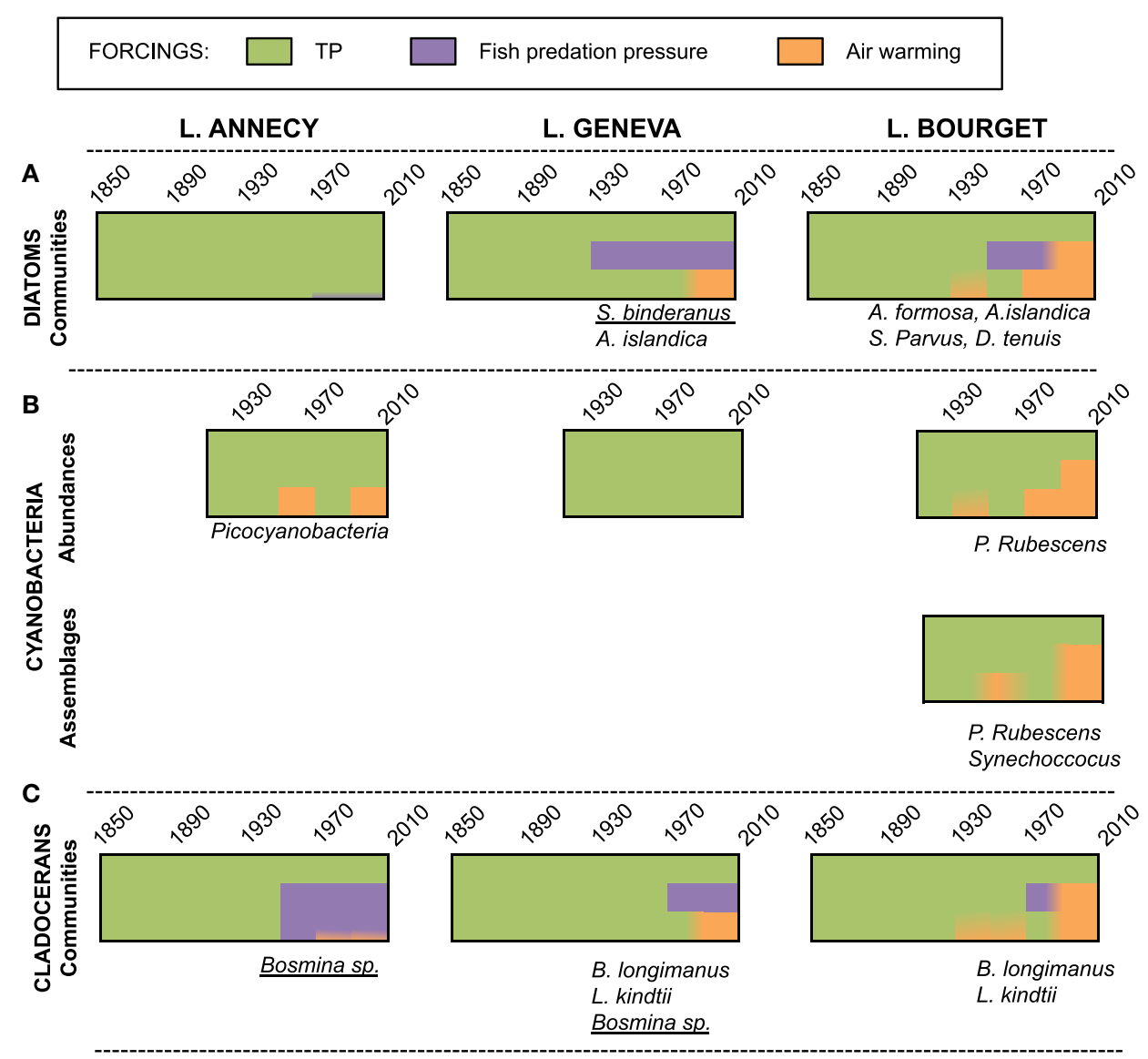

FIGURE 4 | Synthetic view of the relative contribution of local (TP, fish predation pressure) and climate (air temperature warming) forcings to the explained proportion of the planktonic trajectories (A: diatoms, B: cyanobacteria, C: cladocera assemblages) for lakes
Annecy, Geneva, and Bourget. Taxa mentioned below the bars are those that are favored by the recent air warming in each lake, either by direct effects, or through a fish-predation mediated effect (when underlined). transcribed spacer region (Domaizon et al., 2013; Savichtcheva et al., 2014)] were reconstructed over 150 years and the role of climate warming as compared to lake trophic status on the quantitative and qualitative changes was quantified. As for diatoms, changes in TP was the dominant driver of cyanobacteria species successions, even at the scale of picocyanobacterial phylogenetic transitions, while air temperatures had a significant influence on both the colonial/filamentous cyanobacterial and picocyanobacterial abundances (Domaizon et al., 2013; Savichtcheva et al., 2014). Hence, blooming episodes of the toxic $P$. rubescens in Lake Bourget occurred at oligomesotrophic state (i.e., in the 1970s and in the 1990s) but warmer waters in the last quarter of the XXth century amplified their abundances as compared to the 1970s. Current re-oligotrophication Lake Bourget has recently operated a transition from Planktothrix dominance to Anabaena and Microcystis within colonial/filamentous cyanobacterial communities which abundances are yet maintained high by still warming climate (Savichtcheva et al., 2014). Therefore, the consequences of climate warming at all cyanobacterial levels have been conditioned by TP levels in the lakes (Figure 4B).

\section{Zooplankton}

The study of the vulnerability of zooplankters to climate change has been performed through the analysis of parthenogenetic remains (i.e., carapace) for cladocerans and sexual remains (i.e., resting eggs) for Daphnia, relying on microscopic observations and molecular analyses. Parthenogenetic remains result from crustacean molts. In these deep and large U-shaped lakes, the cladoceran remains production, sedimentation, and taphonomic processes within the water column do not alter the compositional fidelity of remain assemblages, which accordingly mirror the composition of parental populations in the water column (Alric and Perga, 2011). In contrast, although egg banks do not necessarily always reflect the extant pelagic population over a short-term scale (Jankowski and Straile, 2003; Keller and Spaak, 2004), they provide a useful archive to investigate the taxonomic (e.g., Weider et al., 1997; Duffy et al., 2000) and evolutionary changes over long-term (e.g., Hairston et al., 1999; Frisch et al., 2014). For cyclical parthenogenetic taxa, the production of resting eggs occurred during an environmentally induced sexual reproduction (Hebert, 1980). Moreover, in sympatry or syntopy, the taxonomic and genetic structure of the egg 
banks depend on the range expansion of species as well as the degree and directionality of gene flow within and between populations (Keller et al., 2008; Cristescu et al., 2012). For cladocerans, both types of remains can be recovered from sediment cores. Following the central position of cladocerans in the food web, as trophic intermediates between primary producers and fish (McQueen et al., 1986, 1989), changes in cladocerans assemblages are likely to respond equally strongly top-down and bottom-up driven local forcings. Otherwise, the opportunity to investigate the temporal genetic architecture of Daphnia spp. populations that occurred in syntopy (i.e., Daphnia longispina species complex), through mitochondrial and microsatellite markers analyses of the resting egg banks, further reinforces our understanding of how the environmental drivers modify the gene flows and subsequent selecting forces.

The contributions of the local and climate forcings on cladoceran community structure over time were very similar to those already depicted for diatoms, except that the contribution of fisheries management practices on climate vulnerability was greater (Alric et al., 2013). As for diatoms, at low nutrient concentration (Lake Annecy), the cladoceran community was essentially controlled by local stressors, with very limited impact of climate warming. The sole detected impact of climate warming was shown to be indirect, favoring small zooplankton species (Bosmina sp.) that can better resist to the high fish predation pressure maintained in this lake by fisheries management practices. In contrast, the more nutrientloaded lakes Geneva and Bourget were more sensitive to climate warming, but, as for diatoms, magnitude of their responses and the pathways under which climate warming affected their communities varied according to the local context of forcings (Figure 4C). Cladoceran assemblages, as for diatoms, are poor paleoclimatic indicators by themselves. Direct impacts of climate warming were indeed only evident for the predatory thermophilic species thriving in warmer, summer waters (Leptodora kindtii, Bythotrephes longimanus). Other community changes attributable to climate warming in the two mesotrophic lakes occurred at least partly through indirect pathways. Climate warming was shown to favor Bosmina species in all three lakes, and this pattern can arise from both strong temperature-dependent growth rates of Bosmina (direct impact, as for Lake Bourget) but also their higher abilities to outcompete Daphnia facing predation (indirect pathways) when fish predation pressure is maintained high by the interaction between fisheries management practices and climate warming (as observed in Lakes Annecy and Geneva).

Beyond their impact at the community level, environmental forcing factors affect the genetic structure of populations (Alric, 2012). Although not conducted at the same highresolution scale, paleo-genetics studies on resting eggs recovered from the sediment cores provided interesting insights on underlying mechanisms by which environmental forcings affect Daphnia populations. At the gene levels, change in TP was the main, but indirect, cause of modifications in genetic structure of Daphnia spp. populations, with TP level that conditioned the magnitude of these changes. Indeed, gene flows within and between populations were higher in the more nutrient-loaded Lakes Geneva and Bourget, compared to Lake Annecy. Environmentally-mediated demographic processes during eutrophication, triggered introgressive hybridization and drastic shift in the genetic structure of the D. longispina species complex. The effect of changes in TP on genetic structure varied between the two lakes depending on the fisheries management practices, while climate warming did not seem to act as a selecting force on the genetic structure of populations (Alric, 2012).

\section{The Vulnerability of the Benthic Habitats to Climate Change}

Both eutrophication and climate warming are expected to trigger severe modifications of benthic conditions, notably oxygen concentrations, with further consequences on faunal composition and metabolic processes (Wiederholm, 1980; Verneaux et al., 2004; Bastviken et al., 2008). The relative share of each of these environmental forcings on past and current benthic oxic conditions remains hard to quantify in absence of long-term data. Long-term trends of changes in lake hypoxia have been previously reconstructed using chironomid subfossil remains (Millet et al., 2010), organic matter preservation and bioturbation index (Ariztegui et al., 2001) or trace metal accumulation (Tribovillard et al., 2006). These approaches, since they rely on a single-core study, usually detected the onset of hypoxia but did not further inform on its spatial extent, i.e., whether it stays limited to the deepest areas, expands, or retracts. Yet, in absence of quantitative estimates, there are limited in their abilities of hierarchizing the environmental drivers of further changes in hypoxic conditions. The lack of such data also hampers our ability to scale the consequences of hypoxia on benthic faunal for which oxygen concentrations are critical. Therefore, we dedicated a specific attention, in the program, to approach benthic processes through a spatially explicit strategy in order to reach quantitative estimates of temporal changes of hypoxia volumes and address the vulnerability of benthic fauna accounting for depths (habitats).

\section{Volumes of Hypoxic Waters}

The preservation of biogeochemical varves, which is favored by the disappearance, following oxygen depletion, of most bioturbating macroorganisms, is a known indicator of the onset of hypoxic conditions (Giguet-Covex et al., 2010). Fine oscillations of hypoxia through complete large lake basins were quantitatively reconstructed by computing the extension of the hypoxic water volumes using multiple sediment cores collected at various depths (40 cores for lake Bourget, 20 for lake Annecy, and 21 for Geneva; Jenny et al., 2013, 2014a).

Even for these lake ecosystems that have been well oxygenated over a millennia-long period, and regardless of past climatic fluctuations, a shift to hypoxic conditions occurred in the 1950s in response to the rise in total phosphorus concentrations above $10 \pm 5 \mu \mathrm{g} \mathrm{P} \mathrm{L}^{-1}$. Following this shift, hypoxia never disappeared in any of three lakes despite the fact that environmental policies succeeded in drastically reducing lake phosphorus concentrations. During that period, decadal fluctuations in hypoxic volume were great, ranging between 0.5 and $8 \%$ of 
the total lake volumes. We demonstrated, through statistical modeling, that these fluctuations were essentially driven by river discharge and air temperature (Jenny et al., 2014a). In lakes Geneva and Bourget, which are fed by large river systems, fluctuations in hypoxic volume were negatively correlated with river discharge. In contrast, in Lake Annecy which is fed by a smaller river system, the expansion of hypoxia was only related to warmer air temperatures. These lakes have inherited hypoxia from the eutrophication period in the 1940-1970s and have shifted to a new stable state, in which hypoxic volumes are now controlled by air temperature and river discharges, independently from changes in lakes TP (Jenny et al., 2014a).

\section{Benthic Fauna}

Further consequences of changes in oxic conditions at the lake sediment interface on the vulnerability of the benthic fauna in result of climate change have been assessed through chironomid assemblages, which head capsules are well preserved in sediment cores. Chironomids have been extensively used to reconstruct past air temperature (e.g., Heiri et al., 2003; Walker and Cwynar, 2006). Nonetheless, in deep stratified lakes, the influence of temperature on chironomids is rather indirect (e.g., duration of thermal stratification) while oxygen constraint directly influences chironomids at a local-scale (e.g., survival and growth rate; Wiederholm, 1980; Verneaux et al., 2004). In order to reach a comprehensive understanding of benthic processes, including littoral and deep habitats, chironomid paleo-surveys have also been conducted over cores sampled at multiple depths (from the maximum lake depth to half of the maximum lake depth, since hypoxia was not likely to settle closer to the lake surface). Such a strategy required a prior identification of the coring transect presenting the better head capsule deposition, by comparison to modern chironomid communities, and therefore ensuring the best-preserved, depth specific chironomid characteristics in the sediment cores (Frossard et al., 2013). The titanic workload of this preliminary task precludes similar multiple depthsstrategy for the very large Lake Geneva. The vulnerability of benthic fauna to climate change has then been studied only on lakes with manageable sizes, i.e., Lakes Annecy and Bourget.

For both lakes, the chironomid assemblages were strongly depth specific and were characterized by oxyphilous taxa (e.g. Micropsectra) at all studied depths before the 1940s. Thereafter, dominant changes of the chironomid assemblages occurred through a drift toward dominance of hypoxia-tolerant taxa (e.g., Sergentia), confirming that oxygen concentration first structures chironomid communities. The sensitivity of chironomid assemblages to the simultaneous environmental forcings was yet depth dependent. Profundal chironomid assemblages (65 $\mathrm{m}$ for Lake Annecy and 145-120 $\mathrm{m}$ for Lake Bourget) responded mainly to nutrient enrichment, whereas assemblages at shallower depths (30-56 m for Lake Annecy; $60-90 \mathrm{~m}$ for Lake Bourget) were mainly affected by topdown effects of the fish community on the pelagic food web, triggering increasing losses of organic matter from the pelagic to the benthic zone. Interestingly, at sub-profundal depth of Lake Annecy (i.e., $56 \mathrm{~m}$ ) and at most studied depths in Lake
Bourget (i.e., 60, 90, 120, and $145 \mathrm{~m}$ ), fluxes of Micropsectra head capsules increased at the onset of eutrophication for roughly a decade prior to collapse (Frossard, 2013). Such humpshaped patterns suggested that eutrophication, prior to trigger deleterious decrease in oxygen concentrations, first promotes food availability to chironomids and therefore enhance their recruitment. Despite obvious re-oligotrophication in both lakes during the latest 30 years, benthic habitats still host mostly hypoxic tolerant species, while the abundance of head capsules have kept on decreasing at the greater depths. Since the late 1980s, increased air temperature significantly contributed in increasing the hypoxic pressure at greater depths, potentially through its effect on the strength and duration of thermal stratification, possibly coupled with changes in mixing efficiency during winter. Therefore, local forcings initially triggered the initial shift in chironomid communities at most depths through their impact on bottom oxic conditions. Since the 1980s though, local forcings do not exert any significant control on the deep fauna. Therefore, although remediation measures have been undertaken locally to minimize local forcings, accumulation, and anoxic preservation of organic matter at the bottom seem to have created a feedback loop that may irreversibly alter carbon cycling in deep habitats (Frossard et al., 2015) and, through hypoxia, increased the repercussions of climate warming on the deep chironomid assemblages. In the sublittoral habitats, the occurrence of hypoxia depends less on climate warming than on whether fisheries management practices maintain an important organic matter loss to the benthos by the cascading top-down effects (Frossard et al., 2013, 2014) (Figure 5).

\section{Lakes Ecological Vulnerability to Climate Warming}

Over the whole century, the lakes ecological trajectories have been predominantly driven by nutrient concentrations. Biodiversity changes due to eutrophication, through direct or indirect (top-down) controls, have been more important than those that could be attributed so far to climate warming, even for Lake Annecy in which eutrophication has been limited. These results echo previous experimental studies showing that the repercussions of climate warming on lakes biodiversity have not yet exceeded those triggered by past and/or current local human activities (Moss et al., 2003; Christoffersen et al., 2006; Ozen et al., 2013). However, all taxonomic groups or processes that we investigated have responded to climate change, in at least two of the three sites, supporting our initial hypotheses that even anthropogenized lakes are vulnerable to climate change. In addition, for most compartments, climatic controls now overpass nutrient controls, suggesting that such a hierarchy in the drivers of lake trajectories might not withstand for long.

Most of what we know about lakes vulnerability to climate change is derived from studies on shallow waterbodies (Mooij et al., 2007; Nielsen et al., 2014). Because of the low heat storage capacity of shallow lakes, water temperatures are not expected to be highly correlated to air temperatures (Adrian et al., 2009; Luoto and Nevalainen, 2013; Winslow et al., 2015), and an increase or imbalance in nutrient concentrations, rather than 


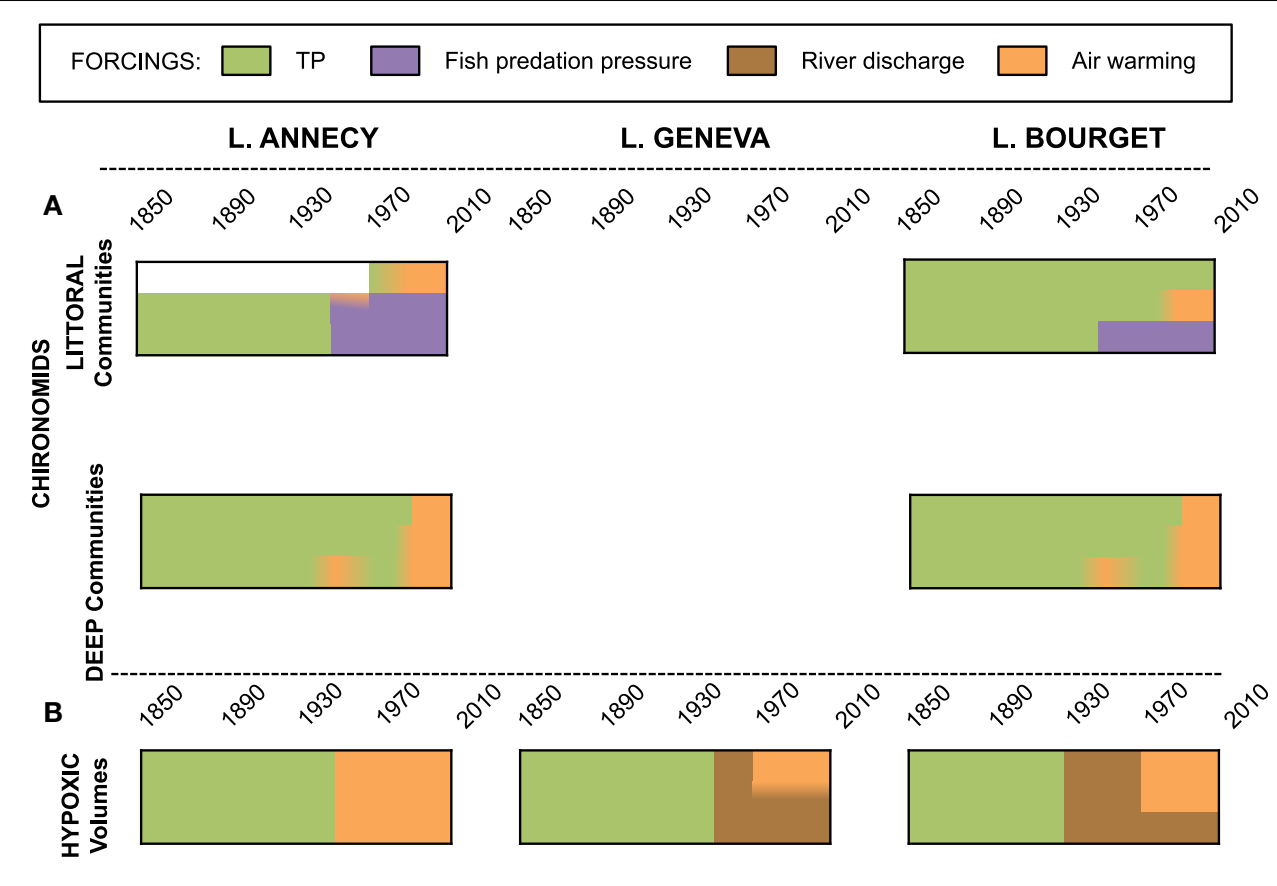

FIGURE 5 | Synthetic view of the relative contribution of local (TP, fish predation pressure, river discharge) and climate (Air warming) forcings to the explained proportion of the benthic trajectories (A: littoral and deep chironomid assemblages; B: hypoxic volumes) for lakes Annecy, Geneva and Bourget. water warming itself, is the primary pathway by which climate change disturbs the ecological state of these lakes (Mooij et al., 2008). Mesocosm experiments consistently showed that water warming per se has only limited repercussions but exacerbates the consequences of nutrient inputs (Christoffersen et al., 2006; Feuchtmayr et al., 2009; Ozen et al., 2013) and this is referred as "warming induced eutrophication." For the large and deep lakes of this study, the general framework is considerably different since phosphorus inputs, which are mostly from domestic and urban origins, have been successfully controlled at the watershed scale, a situation that is similar for many large and deep lakes worldwide (Jeppesen et al., 2005). The absence of warminginduced eutrophication offers the opportunity to evaluate, at an ecosystem-scale and over long-term, how strongly ecological changes attributed to climate warming are actually linked to climate-induced changes in the thermal dynamics.

Of all three lakes, Annecy was the most thermally vulnerable to climate warming, but the one for which planktonic communities were counter-intuitively the least affected. In the two other mesotrophic lakes, the impact of climate change on the ecological trajectories has been strong enough to take over nutrient controls for the last 25 years. Our experimental observations therefore provide strong evidences that climateinduced water warming per se, such as further changes in the lake thermal dynamics, generates limited repercussions on plankton communities, similar to shallow lakes where nutrient are the most determinant constrain. Warming effects on planktonic communities get significant at mesotrophic nutrient levels (Christoffersen et al., 2006; Feuchtmayr et al., 2009; Ozen et al., 2013). The most likely explanation lies on the stoichiometry hypothesis that plankton released from nutrient limitation responds to varying thermal conditions (van de Waal et al., 2009). Most of the experimental works so far have focused on changes in total growth rates or total biomass, suggesting that under warmer waters, nutrient use efficiency might be higher (De Senerpont Domis et al., 2013). Longterm cyanobacterial and pico-cyanobacterial transitions in Lake Bourget support these outputs suggesting that temperaturedependent stoichiometric constrains might also control species transitions under warmer climate (Domaizon et al., 2013; Savichtcheva et al., 2014).

In few cases, planktonic species that have benefited from climate warming are considered as thermophilic species (i.e., that would outcompete other species due to higher growth rates in warmer waters, Lürling et al., 2013). This is indeed the case for the large predatory cladoceran species that now thrive in the waters of Lakes Bourget and Geneva. Otherwise, most planktonic taxa promoted by climate warming are not typical summer species (Alric et al., 2013; Berthon et al., 2014). They instead show life-history traits that more substantially relate to the observed impacts of climate warming on the thermal structure of the water column (either resistance to increased stratification as for Lake Geneva or ability to grow at low light at the end of summer due to a deeper thermocline, i.e., P. rubescens and A. formosa in Lake Bourget) or through predation-mediated pathways cascading down to phytoplankton 


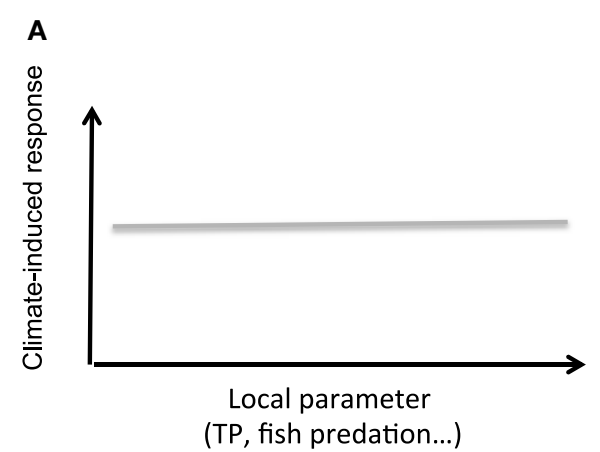

C

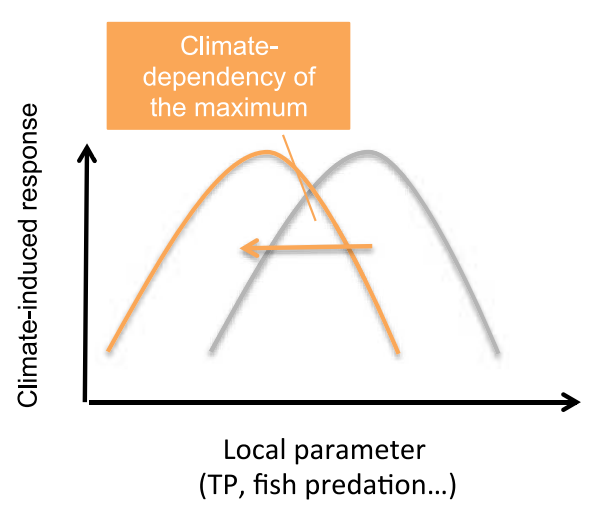

FIGURE 6 | Hypotheses about the link between lake ecological vulnerability to climate warming (amplitude or types of the ecological changes attributed to climate warming) and local environmental forcings under management (TP, fish predation pressure, river

\section{B}

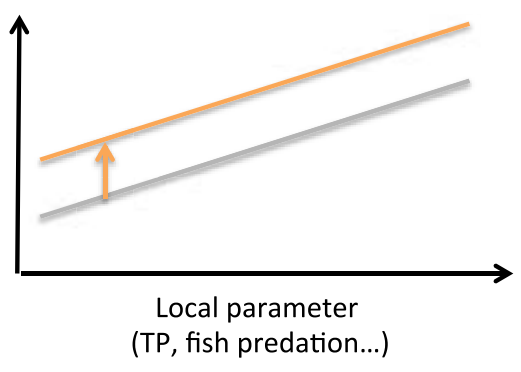

D

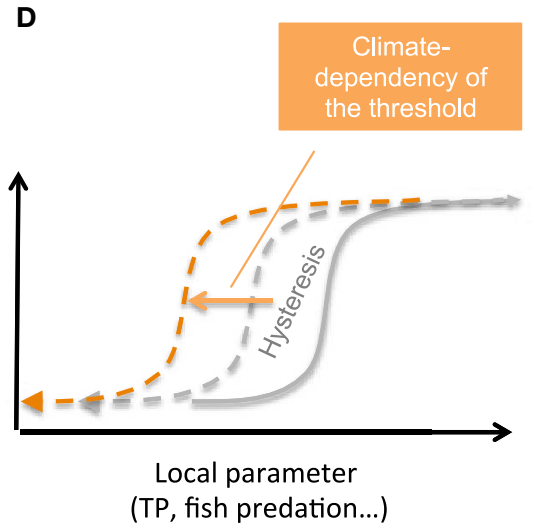

discharge...). (A) Null hypothesis. (B) Linear relationship. (C). Hump-shaped dependency (exhibiting maximum value). (D) Regime shift dependency (exhibiting threshold value). Gray and orange lines depict relationships for current and projected climate change. (cladoceran or diatom tolerance to grazing). The role of topdown controls on plankton seasonal (Sommer et al., 2012), and interannual (Jeppesen et al., 2005) dynamics is currently revised and theoretical or experimental works point to a higher than initially expected contribution to plankton dynamics (Kratina et al., 2012). Climate warming shall, especially in shallow lakes, even reinforce top-down controls by increasing the length of the growing season, per-capita feeding rates and recruitment of zooplanktivorous larval stages (Kratina et al., 2012). Such beneficial consequences of climate warming have also been documented or suggested for the two fish species under management in these lakes: Whitefish Coregonus lavaretus; Anneville et al., 2009, and Perch Perca fluviatilis; Gillet and Dubois, 2007). The paleo-ecological approach provided solid, long-term ecosystem-scale evidence of fish predation pressure controlling zooplankton community structure, cascading down to phytoplankton assemblages and even organic matter export to the sediments. The predation-mediated pathways by which climate structures planktonic communities and at some point littoral benthic communities, were even reinforced by local fisheries management practices in Lakes Geneva and Annecy.

The vulnerability of planktonic communities to climate warming in these large and deep lakes was therefore rather independent from their thermal vulnerability. The direct physiological impacts of warmer waters on plankton life cycle and species transitions are not likely the most significant pathways by which climate warming alters planktonic communities in these lakes. Instead, nutrient constrains and fish predation pressure interplay with climate change, regulating the sensitivity of the communities to water warming and subsequent climateinduced hydrodynamic changes and creating multiple, indirect pathways which exert a dominant structuring impact on surface (planktonic and littoral) communities structures.

In contrast to planktonic communities on which TP drove continuous species transitions over the last century, benthic community changes were abrupt. Depth-changes in benthic communities mirrored the onset and expansion of hypoxia at the lake bottom. TP acted as a trigger of hypoxia, but above a relatively low threshold (around $10 \mu \mathrm{g}$ P.L ${ }^{-1}$, i.e., upper limit of oligotrophy), further expansion or contraction of hypoxic volumes have not been anymore controlled by further changes in TP. There have been, instead, driven by climatic and hydrological forcings, that regulate oxygen replenishment at the bottom by winter mixing or river inputs. Therefore, benthic trajectories are discontinuous and the legacy of past eutrophication, even limited, has triggered significant regime shifts that are mediated by the accumulation and respiration 
of organic matter. While surface (pelagic and sub-littoral) communities are still responding to changes in local forcings, deep biodiversity, and oxic conditions seem currently almost only regulated by climatic factors (river discharges being under both local and climatic controls). Surface and deep habitats are therefore currently uncoupled in these three lakes since they now respond to a different set of forcings along varying dynamical regimes.

Operational conclusions of the program would be that local management strategies could help minimizing the impacts of climate warming on lake ecological processes and biodiversity. Surface habitats still respond to both local and climate forcings. Therefore, pursuing efforts to reduce TP inputs to the lake and adaptation of management practices could help to limit the climate impacts on the pelagic food web. For instance, adapted stocking practices, schedule or fishing regulation could significantly limit cascading effects of fish predation pressure on the food web and avoid amplification of these effects by climate change in these lakes, i.e., the development of large cyanobacteria or unedible phytoplankton species, and further counter organic matter export to the sediment and maintenance of littoral hypoxic conditions. Further research is yet required to test the robustness of such conclusions on a larger set of sites (Figure 6). What remains unclear is the shape (discontinuous, continuous, or gradual; Kefi et al., 2013) of the relationships linking the local parameter (TP, fish predation pressure) to the qualitative and quantitative response of the surface communities or processes under climate warming. Such information would be crucial to help managers to set target TP or fisheries management practices in order to limit lake vulnerability to climate change and ultimately promote ecosystem services. For benthic, deep habitats, hydrologic regulation of river discharge might be, for lakes fed by large river systems, a control lever on which managers might act to limit deep-water hypoxia. Preservation of part of the natural river flow is long known as a powerful way to protect the ecological integrity of river ecosystems (Richter

\section{References}

Adrian, R., O’Reilly, C. M., Zagarese, H., Baines, S. B., Hessen, D. O., Keller, W., et al. (2009). Lakes as sentinels of climate change. Limnol. Oceanogr. 54, 2283-2297. doi: 10.4319/lo.2009.54.6_part_2.2283

Alric, B. (2012). The Vulnerability of Lakes Face to the Coupling of Climate and Local Disturbance: Paleolimnological Approach Based on Cladocerans. Université de Grenoble.

Alric, B., Jenny, J. P., Berthon, V., Arnaud, F., Pignol, C., Reyss, J. L., et al. (2013). Local forcings affect lake zooplankton vulnerability and response to climate warming. Ecology 94, 2767-2780. doi: 10.1890/12-1903.1

Alric, B., and Perga, M. E. (2011). Effects of production, sedimentation and taphonomic processes on the composition and size structure of sedimenting cladoceran remains in a large deep subalpine lake: paleoecological implications. Hydrobiologia 676, 101-116. doi: 10.1007/s10750-0110868-0

Anneville, O., Beniston, J., Gallina, N., Gillet, C., Jacquet, S., Lazzarotto, J., et al. (2013). L'empreinte du changement climatique sur le Léman. Archiv. Sci. 66, 157-172.

Anneville, O., Souissi, S., Molinero, J. C., and Gerdeaux, D. (2009). Influences of human activity and climate on the stock-recruitment dynamics of whitefish, et al., 2003) but has only recently been considered within some still rare lake management plans. Although this kind of initiative could benefit bottom oxygenation by releasing its dependency to climate warming, the relationship between TP and hypoxic volumes clearly follows a regime shift dynamics which first threshold was at $10 \mu \mathrm{g}$ P.L ${ }^{-1}$. Lack of recovery of bottom oxic conditions for Lake Annecy, although TP has crossed the threshold line already a decade ago, suggests that accumulation of organic matter is a legacy that generates hysteretic dynamics. The value of the next threshold of recovery is therefore uncertain and might also further decrease depending on further warming scenarios (Figures 6C,D), as already modeled for shallow lakes (Nielsen et al., 2014). A next step and perspective of this IPERRETRO research program, that is currently undertaken, is to compare multiple trajectories of similar peri-alpine lakes in order to detect and test these hypothetic relationships and investigate potential thresholds.

\section{Author Contributions}

All authors contributed to the acquisition, analysis and interpretation of data for the presented work and approved the present manuscript. MP, CP, VF, JJ, and BA substantially contributed to build up this synthesis.

\section{Acknowledgments}

We thank the two anonymous reviewers which comments improved the initial version of this manuscript. This study has been primarily supported by the French National Research Agency (ANR-VUL 005: IPER-RETRO project) with additional funding from the "Association des Pays de Savoie" to JJ, the INEE (CNRS France), who supported the PEPS program ADNmessager to ID and OS, the "innovative projects" and "invited professors" fundings from INRA to BA, OS, and ID, and Université de Savoie to VB.
Coregonus lavaretus, in Lake Geneva. Fish. Manag. Ecol. 16, 492-500. doi: 10.1111/j.1365-2400.2009.00703.x

Ariztegui, D., Chondrogianni, C., Lami, A., Guilizzoni, P., and Lafargue, E. (2001). Lacustrine organic matter and the Holocene paleoenvironmental record of Lake Albano (central Italy). J. Paleolimnol. 26, 283-292. doi: 10.1023/A:1017585808433

Auer, I., Bohm, R., Jurkovic, A., Lipa, W., Orlik, A., Potzmann, R., et al., (2007). HISTALP - historical instrumental climatological surface time series of the Greater Alpine Region. Int. J. Climatol. 27, 17-46. doi: 10.1002/ joc. 1377

Bastviken, D., Cole, J. J., Pace, M. L., and Van de Bogert, M. C. (2008). Fates of methane from different lake habitats: connecting whole-lake budgets and CH4 emissions. J. Geophys. Res. Biogeosci. 113, G02024. doi: 10.1029/2007JG 000608

Battarbee, R. W. (2000). Palaeolimnological approaches to climate change, with special regard to the biological record. Quat. Sci. Rev. 19, 107-124. doi: 10.1016/S0277-3791(99)00057-8

Battarbee, R. W. (2010). "Aquatic ecosystem variability and climate changea palaeoecological perspective," in Climate Change Impacts on Freshwater Ecosystems, eds M. Kernan, R.W. Battarbee, and B. Moss (Oxford: WileyBlackwell), 15-37. doi: 10.1002/9781444327397.ch2 
Beniston, M. (2006). Mountain weather and climate: a general overview and a focus on climatic change in the Alps. Hydrobiologia 562, 3-16. doi: 10.1007/s10750005-1802-0

Berthon, V., Alric, B., Rimet, F., and Perga, M.-E. (2014). Sensitivity and responses of diatoms to climate warming in lakes heavily influenced by humans. Freshw. Biol. 59, 1755-1767. doi: 10.1111/fwb.12380

Berthon, V., Marchetto, A., Rimet, F., Dormia, E., Jenny, J. P., Pignol, C., et al. (2013). Trophic history of French sub-alpine lakes over the last $\sim 150$ years: phosphorus reconstruction and assessment of taphonomic biases. J. Limnol. 72, 417-429. doi: 10.4081/jlimnol.2013.e34

Blenckner, T. (2005). A conceptual model of climate-related effects on lake ecosystems. Hydrobiologia 533, 1-14. doi: 10.1007/s10750-004-1463-4

Boere, A. C., Rijpstra, W. I. C., De Lange, G. J., Sinninghe Damsté, J. S., and Coolen, M. J. (2011). Preservation potential of ancient plankton DNA in pleistocene marine sediments. Geobiology 9, 377-393. doi: 10.1111/j.1472-4669. 2011.00290.x

Burgmer, T., Hillebrand, H., and Pfenninger, M. (2007). Effects of climatedriven temperature changes on the diversity of freshwater macroinvertebrates. Oecologia 151, 93-103. doi: 10.1007/s00442-006-0542-9

Christoffersen, K., Andersen, N., Sondergaard, M., Liboriussen, L., and Jeppesen, E. (2006). Implications of climate-enforced temperature increases on freshwater pico- and nanoplankton populations studied in artificial ponds during 16 months. Hydrobiologia 560, 259-266. doi: 10.1007/s10750-005-1221-2

Coolen, M. J. L., Talbot, H. M., Abbas, B. A., Ward, C., Schouten, S., Volkman, J. K., et al. (2008). Sources for sedimentary bacteriohopanepolyols as revealed by 16s rdna stratigraphy. Environ. Microbiol. 10, 1783-1803. doi: 10.1111/j.14622920.2008.01601.x

Cristescu, M. E., Constantin, A., Bock, D. G., Cáceres, C. E., and Crease, T. J. (2012). Speciation with gene flow and the genetics of habitat transitions. Mol. Ecol. 21, 1411-1422. doi: 10.1111/j.1365-294X.2011.05465.x

Danis, P.-A., von Grafenstein, U., Masson-Delmotte, V., Planton, S., Gerdeaux, D., and Moisselin, J. M. (2004). Vulnerability of two European lakes in response to future climatic changes. Geophys. Res. Lett. 31, L21507. doi: 10.1029/2004 GL020833

De Senerpont Domis, L. N., Van de Waal, D. B., Helmsing, N. R., Van Donk, E., and Mooij, W. M. (2013). Community stoichiometry in a changing world: combined effects of warming and eutrophication on phytoplankton dynamics. Ecology 95, 1485-1495. doi: 10.1890/13-1251.1

De Stasio, B. T. Jr., Kill, D. K., Kleinhans, J., Nibbelink, N., and Magnuson, J. J. (1996). Potential effects of global climate change on small north-temperate lakes:physics, fish, and plankton. Limnol. Oceanogr. 41, 1136-1149. doi: 10.4319/lo.1996.41.5.1136

Dokulil, M. T. (2014). Impact of climate warming on European inland waters. Inland Waters 4, 27-40. doi: 10.5268/IW-4.1.705

Dokulil, M. T., Jagsch, A., George, G. D., Anneville, O., Jankowski, T., Wahl, B., et al., (2006). Twenty years of spatially coherent deepwater warming in lakes across Europe related to the North Atlantic Oscillation. Limnol. Oceanogr. 51, 2787-2793. doi: 10.4319/lo.2006.51.6.2787

Dokulil, M. T., and Teubner, K. (2002). The spatial coherence of alpine lakes. Verh. Internat. Verein. Limnol. 28, 1861-1864.

Domaizon, I., Savichtcheva, O., Debroas, D., Arnaud, F., Vilar, C., Pignol, C., et al. (2013). DNA from lake sediments reveals the long-term dynamics and diversity of Synechococcus assemblages. Biogeosciences 10, 2515-2564. doi: 10.5194/bgd-10-2515-2013

Dong, X. H., Bennion, H., Maberly, S. C., Sayer, C. D., Simpson, G. L., and Battarbee, R. W. (2012). Nutrients exert a stronger control than climate on recent diatom communities in Esthwaite Water: evidence from monitoring and palaeolimnological records. Freshw. Biol. 57, 2044-2056. doi: 10.1111/j.13652427.2011.02670.x

Duffy, M. A., Perry, L. J., Kearns, C. M., Weider, L. J., and Hairston, J. N. G. (2000). Paleogenetic evidence for a past invasion of Onondaga Lake, New York, by exotic Daphnia curvirostris using mtDNA from dormant eggs. Limnol. Oceanogr. 45, 1409-1414. doi: 10.4319/lo.2000.45.6.1409

Epp, L., Stoof-Leichsenring, K. R., Trauth, M. H., and Tiedemann, R. (2011). Molecular profiling of diatom assemblages in tropical lake sediments using taxon-specific PCR and Denaturing High-Performance Liquid Chromatography (PCR-DHPLC). Mol. Ecol. Resour. 11, 842-853. doi: $10.1111 / j .1755-0998.2011 .03022 . x$
Fee, E. J., Hecky, R. E., Kasian, S. E. M., and Cruikshank, D. R. (1996). Effects of lake size, water clarity, and climatic variability on mixing depths in Canadian Shield lakes. Limnol. Oceanogr. 41, 912-920. doi: 10.4319/lo.1996.41.5.0912

Feuchtmayr, H., Moran, R., Hatton, K., Connor, L., Heyes, T., Moss, B., et al. (2009). Global warming and eutrophication: effects on water chemistry and autotrophic communities in experimental hypertrophic shallow lake mesocosms. J. Appl. Ecol. 46, 713-723. doi: 10.1111/j.1365-2664.2009. 01644.x

Frisch, D., Morton, P. K., Chowdhury, P. R., Culver, B. W., Colbourne, J. K., Weider, L. J., et al. (2014). A millennial-scale chronicle of evolutionary responses to cultural eutrophication in Daphnia. Ecol. Lett. 17, 360-368. doi: 10.1111/ele.12237

Frossard, V. (2013). Trajectoires Écologiques des Lacs d'Annecy et du Bourget au Cours des 150 Dernières Années: Approche Paléolimnologique par L'Analyse des Assemblages de Chironomidae (Diptera) et de Leurs Signatures Isotopiques en Carbone. Ph.D. Université de Franche comté.

Frossard, V., Millet, L., Verneaux, V., Jenny, J. P., Arnaud, F., Magny, M., et al. (2014). Depth-specific responses of a chironomid assemblage to contrasting anthropogenic pressures: a palaeolimnological perspective from the last 150 years. Freshw. Biol. 59, 26-40. doi: 10.1111/fwb.12243

Frossard, V., Millet, L., Verneaux, V., Jenny, J. P., Arnaud, F., Magny, M., et al. (2013). Chironomid assemblages in cores from multiple water depths reflect oxygen-driven changes in a deep French lake over the last 150 years. J. Paleolimnol. 50, 257-273. doi: 10.1007/s10933-013-9722-x

Frossard, V., Verneaux, V., Millet, L., Magny, M., and Perga, M. E. (2015). Changes in carbon sources fueling benthic secondary production over depth and time: coupling Chironomidae stable carbon isotopes to larval abundance. Oecologia 178, 603-614. doi: 10.1007/s00442-015-3225-6

Giguet-Covex, C., Arnaud, F., Poulenard, J., Enters, D., Reyss, J. L., Millet, L., et al. (2010). Sedimentological and geochemical records of past trophic state and hypolimnetic anoxia in large, hard-water Lake Bourget, French Alps. J. Paleolimnol. 43, 171-190. doi: 10.1007/s10933-009-9324-9

Gillet, C., and Dubois, J. P. (2007). Effect of water temperature and size of females on the timing of spawning of perch Perca fluviatilis L. in Lake Geneva from 1984 to 2003. J. Fish Biol. 70, 1001-1014. doi: 10.1111/j.1095-8649.2007.01359.x

Hairston, J. N. G., Lampert, W., Cáceres, C. E., Holtmeier, C. L., Weider, L. J., Gaedke, U., et al. (1999). Rapid evolution revealed by dormant eggs. Nature 401, 446-446. doi: 10.1038/46731

Hebert, P. D. N. (1980). "The genetics of cladocera," in Evolution and Ecology of Zooplankton Communities, ed W. C. Kerfoot (New Hampshire: University Press of New England), 329-336.

Heiri, O., Lotter, A. F., Hausmann, S., and Kienast, F. (2003). A chironomidbased Holocene summer air temperature reconstruction from the Swiss Alps. Holocene 13, 477-484. doi: 10.1191/0959683603hl640ft

Hering, D., Haidekker, A., Schmidt-Kloiber, A., Barker, T., Buisson, L., Graf, W., et al. (2010). "Monitoring the responses of freshwater ecosystems to Climate change," in Climate Change Impacts on Freshwater Ecosystems, eds M. Kernan, R.W. Battarbee, and B. Moss (Oxford: Wiley-Blackwell), 84-117. doi: 10.1002/9781444327397.ch5

Hobæk, A., Løvik, J. E., Rohrlack, T., Moe, S. J., Grung, M., Bennion, H., et al. (2012). Eutrophication, recovery and temperature in Lake Mjøsa: detecting trends with monitoring data and sediment records. Freshw. Biol. 57, 1998-2014. doi: $10.1111 / j .1365-2427.2012 .02832 . x$

Jacquet, S., Briand, J. F., Leboulanger, C., Avois-Jacquet, C., Oberhaus, L., Tassin, B., et al. (2005). The proliferation of the toxic cyanobacterium Planktothrix rubescens following restoration of the largest natural French lake (Lac du Bourget). Harmful Algae 4, 651-672. doi: 10.1016/j.hal.2003.12.006

Jankowski, T., and Straile, D. (2003). A comparison of egg-bank and longterm plankton dynamics of two Daphnia species, D. hyalina and D. galeata: potentials and limits of reconstruction. Limnol. Oceanogr. 48, 1948-1955. doi: 10.4319/lo.2003.48.5.1948

Jenny, J. P., Arnaud, F., Alric, B., Dorioz, J. M., Sabatier, P., Meybeck, M., et al. (2014a). Inherited hypoxia: a new challenge for reoligotrophicated lakes under global warming. Glob. Biogeochem. Cycles 28, 1413-1423. doi: 10.1002/2014GB004932

Jenny, J. P., Arnaud, F., Dorioz, J. M., Giguet-Covex, C., Frossard, V., Sabatier, P., et al. (2013). A spatiotemporal investigation of varved sediments highlights the dynamics of hypolimnetic hypoxia in a large hard-water lake over the 
last 150 years. Limnol. Oceanogr. 58, 1395-1408. Doi: 10.4319/lo.2013.58. 4.1395

Jenny, J. P., Wilhelm, B., Arnaud, F., Sabatier, P., Covex, C. G., Melo, A., et al. (2014b). A 4D sedimentological approach to reconstructing the flood frequency and intensity of the Rhne River (Lake Bourget, NW European Alps). J. Paleolimnol. 51, 469-483. doi: 10.1007/s10933-014-9768-4

Jeppesen, E., Sondergaard, M., Jensen, J. P., Havens, K. E., Anneville, O., Carvalho, L., et al. (2005). Lake responses to reduced nutrient loading - an analysis of contemporary long-term data from 35 case studies. Freshw. Biol. 50, 1747-1771. doi: 10.1111/j.1365-2427.2005.01415.x

Kefi, S., Dakos, V., Scheffer, M., Van Nes, E. H., and Rietkerk, M. (2013). Early warning signals also precede non-catastrophic transitions. Oikos 122, 641-648. doi: 10.1111/j.1600-0706.2012.20838.x

Keller, B., and Spaak, P. (2004). Nonrandom sexual reproduction and diapausing egg production in a Daphnia hybrid species complex. Limnol. Oceanogr. 49, 1393-1400. doi: 10.4319/lo.2004.49.4_part_2.1393

Keller, B., Wolinska, J., Manca, M., and Spaak, P. (2008). Spatial, environmental and anthropogenic effects on the taxon composition of hybridizing Daphnia. Philos. Trans. R. Soc. Lond. B. Biol. Sci. 363, 2943-2952. doi: 10.1098/rstb.2008.0044

Kernan, M., Moss, B., and Battarbee, R. W. (Eds.). (2010). Climate Change impacts on Freshwater. (Oxford: Wiley Blackwell), 314. doi: 10.1002/9781444327397

Kratina, P., Greig, H. S., Thompson, P. L., Carvalho-Pereira, T. S. A., and Shurin, J. B. (2012). Warming modifies trophic cascades and eutrophication in experimental freshwater communities. Ecology 93, 1421-1430. doi: 10.1890/111595.1

Leavitt, P. R., Fritz, S. C., Anderson, N. J., Baker, P. A., Blenckner, T., Bunting, L., et al. (2009). Paleolimnological evidence of the effects on lakes of energy and mass transfer from climate and humans. Limnol. Oceanogr. 54, 2330-2348. doi: 10.4319/lo.2009.54.6_part_2.2330

Livingstone, D. M., Adrian, R., Arvola, L., Bleckner, T., Dokulil, M. T., Hari, R. E., et al. (2010). "Regional and supra-regional cohernce in Limnological variables," in The Impact of Climate Change on European lakes, ed G. George (Dordrecht: Springer), 311-337. doi: 10.1007/978-90-481-2945-4_17

Livingstone, D. M., and Dokulil, M. T. (2001). Eighty years of spatially coherent Austrian lake surface temperatures and their relationship to regional air temperature and the North Atlantic Oscillation. Limnol. Oceanogr. 46, 1220-1227. doi: 10.4319/lo.2001.46.5.1220

Livingstone, D. M., and Padisak, J. (2007). Large-scale coherence in the response of lake surface-water temperatures to synoptic-scale climate forcing during summer. Limnol. Oceanogr. 52, 896-902. doi: 10.4319/lo.2007.52.2.0896

Luoto, T. P., and Nevalainen, L. (2013). Long-term water temperature reconstructions from mountain lakes with different catchment and morphometric features. Sci. Rep. 3:2488. doi: 10.1038/srep02488

Lürling, M., Eshetu, F., Faassen, E. J., Kosten, S., and Huszar, V. L. M. (2013). Comparison of cyanobacterial and green algal growth rates at different temperatures. Freshw. Biol. 58, 552-559. doi: 10.1111/j.1365-2427.2012.02866.x

Magnuson, J. J., Webster, K. E., Assel, R. A., Bowser, C. J., Dillon, P. J., Eaton, J. G., et al. (1997). Potential effects of climate changes on aquatic systems: Laurentian Great Lakes and Precambrian Shield Region. Hydrol. Process. 11, 825-871.

Marchetto, A., and Benedetti, R. (1995). Reconstruction of the phosphorus history of two deep, subalpine Italian lakes from sedimentary diatoms, compared with long-term chemical measurements. Mem. Ist. Ital. Idrobiol. 53, 27-38.

Marchetto, A., Lami, A., Musazzi, S., Massaferro, J., Langone, L., and Guilizzoni, P. (2004). Lake Maggiore (N. Italy) trophic history: fossil diatom, plant pigments, and chironomids, and comparison with long-term limnological data. Quaternary Int. 113, 97-110. doi: 10.1016/S1040-6182(03) 00082-X

McQueen, D. J., Johannes, M. R. S., Post, J. R., Stewart, T. J. and Lean, D. R. S. (1989). Bottom-up and top-down impacts on freshwater pelagic community structure. Ecol. Monogr. 59, 289-309. doi: 10.2307/1942603

McQueen, D. J., Post, J. R., and Mills, E. L. (1986). Trophic relationships in freshwater pelagic ecosystems. Can. J. Fish. Aquat. Sci. 43, 1571-1581. doi: 10.1139/f86-195

Meybeck, M. (1995). "Les lacs et leur bassin," in Limnologie générale, eds R. Pourriot and M. Meybeck (Masson: Paris Milan Barcelone), 6-59.

Millet, L., Giguet-Covex, C., Verneaux, V., Druart, J. C., Adatte, T., and Arnaud, F. (2010). Reconstruction of the recent history of a large deep prealpine lake (Lake
Bourget, France) using subfossil chironomids, diatoms, and organic matter analysis: towards the definition of a lake-specific reference state. J. Paleolimnol. 44, 963-978. doi: 10.1007/s10933-010-9467-8

Mooij, W. M., Domis, L. N. D. S., and Hulsmann, S. (2008). The impact of climate warming on water temperature, timing of hatching and young-of-the-year growth of fish in shallow lakes in the Netherlands. J. Sea Res. 60, 32-43. doi: 10.1016/j.seares.2008.03.002

Mooij, W. M., Janse, J. H., Domis, L. N. D. S., Hulsmann, S., and Ibelings, B. W. (2007). Predicting the effect of climate change on temperate shallow lakes with the ecosystem model PCLake. Hydrobiologia 584, 443-454. doi: 10.1007/s10750-007-0600-2

Moss, B., McKee, D., Atkinson, D., Collings, S. E., Eaton, J. W., Gill, A. B., et al. (2003). How important is climate? Effects of warming, nutrient addition and fish on phytoplankton in shallow lake microcosms. J. Appl. Ecol. 40, 782-792. doi: 10.1046/j.1365-2664.2003.00839.x

Nielsen, A., Trolle, D., Bjerring, R., Sondergaard, M., Olesen, J. E., Janse, J. H., et al. (2014). Effects of climate and nutrient load on the water quality of shallow lakes assessed through ensemble runs by PCLake. Ecol. Appl. 24, 1926-1944. doi: 10.1890/13-0790.1

Ozen, A., Sorf, M., Trochine, C., Liboriussen, L., Beklioglu, M., Sondergaard, M., et al. (2013). Long-term effects of warming and nutrients on microbes and other plankton in mesocosms. Freshw. Biol. 58, 483-493. doi: 10.1111/j.13652427.2012.02824.x

Perga, M. E. (2010). Potential of $\delta^{13} \mathrm{C}$ and $\delta^{15} \mathrm{~N}$ of cladoceran subfossil exoskeletons for paleo-ecological studies. J. Paleolimnol. 44, 387-395. doi: 10.1007/s10933-009-9340-9

Perga, M. E. (2011). Taphonomic and early diagenetic effects on the $\mathrm{C}$ and $\mathrm{N}$ stable isotope composition of cladoceran remains: implications for paleoecological studies. J. Paleolimnol. 46, 203-213. doi: 10.1007/s10933-011-9532-y

Perga, M. E., Bec, A., and Anneville, O. (2009). Origins of carbon sustaining the growth of whitefish Coregonus lavaretus early larval stages in Lake Annecy: insights from fatty-acid biomarkers. J. Fish Biol. 74, 2-17. doi: 10.1111/j.10958649.2008.02105.x

Reyjol, Y., Argillier, C., Bonne, W., Borja, A., Buijse, A. D., Cardoso, A. C., et al. (2014). Assessing the ecological status in the context of the European Water Framework Directive: where do we go now? Sci. Total Environ. 497, 332-344. doi: 10.1016/j.scitotenv.2014.07.119

Richter, B. D., Mathews, R., Harrison, D. L., and Wigington, R. (2003). Ecologically sustainable water management: managing river flows for ecological integrity. Ecol. Appl. 13, 206-224. doi: 10.1890/1051-0761(2003)013[0206:ESWMMR]2.0.CO;2

Rühland, K., Paterson, A. M., and Smol, J. P. (2008). Hemispheric-scale patterns of climate-related shifts in planktonic diatoms from North American and European lakes. Glob. Change Biol. 14, 2740-2754. doi: 10.1111/j.13652486.2008.01670.x

Savichtcheva, O., Debroas, D., Kurmayer, R., Villar, C., Jenny, J. P., Arnaud, F., et al. (2011). Quantitative PCR enumeration of total/toxic planktothrix rubescens and total cyanobacteria in preserved DNA isolated from lake sediments. Appl. Environ. Microbiol. 77, 8744-8753. doi: 10.1128/AEM.06106-11

Savichtcheva, O., Debroas, D., Perga, M. E., Arnaud, F., Villar, C., Lyautey, E., et al. (2014). Effects of nutrients and warming on Planktothrix dynamics and diversity: a palaeolimnological view based on sedimentary DNA and RNA. Freshw. Biol. 60, 31-49. doi: 10.1111/fwb.12465

Schindler, D. W., Bayley, S. E., Parker, B. R., Beaty, K. G., Cruikshank, D. R., Fee, E. J., et al., (1996). The effects of climatic warming on the properties of boreal lakes and streams at the Experimental Lakes Area, northwestern Ontario. Limnol. Oceanogr. 41, 1004-1017. doi: 10.4319/lo.1996.41.5.1004

Shurin, J. B., Clasen, J. L., Greig, H. S., Kratina, P., and Thompson, P. L. (2012). Warming shifts top-down and bottom-up control of pond food web structure and function. Philos. Trans. R. Soc. B Biol. Sci. 367, 3008-3017. doi: $10.1098 /$ rstb. 2012.0243

Simpson, G. L., and Anderson, N. J. (2009). Deciphering the effect of climate change and separating the influence of confounding factors in sediment core records using additive models. Limnol. Oceanogr. 54, 2529-2541.

Smol, J. P., Wolfe, A. P., Birks, H. J. B., Douglas, M. S., Jones, V. J., Korhola, A., et al. (2005). Climate-driven regime shifts in the biological communities of arctic lakes. Proc. Natl. Acad. Sci. U.S.A. 102, 4397-4402. doi: $10.1073 /$ pnas.0500245102 
Sommer, U., Adrian, R., De Senerpont Domis, L., Elser, J. J., Gaedke, U., Ibelings, B., et al. (2012). Beyond the Plankton Ecology Group (PEG) model: mechanisms driving plankton succession. Annu. Rev. Ecol. Evol. Syst. 43, 429-448. doi: 10.1146/annurev-ecolsys-110411-160251

Sterner, R. W. (1993). Daphnia growth on varying quality of scenedesmus - mineral limitation of zooplankton. Ecology 74, 2351-2360. doi: 10.2307/1939587

Tapolczai, K., Anneville, O., Padisak, J., Salmaso, N., Morabito, G., Zohary, T., et al. (2015). Occurrence and mass development of Mougeotia spp. (Zygnemataceae) in large, deep lakes. Hydrobiologia 745, 17-29. doi: 10.1007/s10750-014-2086-Z

ter Heerdt, G. N. J., Schep, S. A., Janse, J. H., and Ouboter, M. (2007). Climate change and the EU water framework directive: how to deal with indirect effects of changes in hydrology on water quality and ecology? Water Sci. Technol. 56, 19-26. doi: 10.2166/wst.2007.532

Thies, H., Tolotti, M., Nickus, U., Lami, A., Musazzi, S., Guilizzoni, P., et al. (2011). Interactions of temperature and nutrient changes: effects on phytoplankton in the Piburger See (Tyrol, Austria). Freshw. Biol. 57, 2057-2075. doi: 10.1111/j.1365-2427.2011.02661.x

Tribovillard, N., Algeo, T. J., Lyons, T., and Riboulleau, A. (2006). Trace metals as paleoredox and paleoproductivity proxies: an update. Chem. Geol. 232, 12-32. doi: 10.1016/j.chemgeo.2006.02.012

Ulen, B. M., and Weyhenmeyer, G. A. (2007). Adapting regional eutrophication targets for surface waters - influence of the EU water framework directive national policy and climate change. Environ. Sci. Policy 10, 734-742. doi: 10.1016/j.envsci.2007.04.004

Urabe, J., Clasen, J., and Sterner, R. W. (1997). Phosphorus limitation of daphnia growth: Is it real? Limnol. Oceanogr. 42, 1436-1443. doi: 10.4319/lo.1997.42.6.1436

van de Waal, D. B., Verschoor, A. M., Verspagen, J. M. H., Van Donk, E., and Huisman, J. (2009). Climate-driven changes in the ecological stoichiometry of aquatic ecosystems. Front. Ecol. Environ. 8, 145-152. doi: 10.1890/080178

Verneaux, V., Verneaux, J., Schmitt, A., and Lambert, J. C. (2004). Relationships of macrobenthos with dissolved oxygen and organic matter at the sediment-water interface in ten French lakes. Arch. Hydrobiol. 160, 247-259. doi: 10.1127/00039136/2004/0160-0247

Vincon-Leite, B., Lemaire, B. J., Khac, V. T., and Tassin, B. (2014). Long-term temperature evolution in a deep sub-alpine lake, Lake Bourget, France: how a one-dimensional model improves its trend assessment. Hydrobiologia 731, 49-64. doi: 10.1007/s10750-014-1818-4

Walker, I., and Cwynar, L. (2006). Midges and palaeotemperature reconstructionthe North American experience. Quat. Sci. Rev. 25, 1911-1925 doi: 10.1016/j.quascirev.2006.01.014
Webster, K. E., Kratz, T. K., Bowser, C. J., Magnuson, J. J., and Rose, W. J. (1996). The influence of landscape position on lake chemical responses to drought in northern Wisconsin. Limnol. Oceanogr. 41, 977-984. doi: 10.4319/lo.1996.41.5.0977

Weider, L. J., Lampert, W., Wessels, M., Colbourne, J. K., and Limburg, P. (1997). Long-term genetic shifts in a microcrustacean egg bank associated with anthropogenic changes in the Lake Constance ecosystem. Proc. Biol. Sci. 264 1613-1618. doi: 10.1098/rspb.1997.0225

Wiederholm, T. (1980). Use of benthos in lake monitoring. J. Water Pollut. Control Fed. 52, 537-547.

Willerslev, E., Cappellini, E., Boomsma, W., Nielsen, R., Hebsgaard, M. B., Brand, T. B., et al. (2007). Ancient biomolecules from deep ice cores reveal a forested southern greenland. Science 317, 111-114. doi: 10.1126/science.1141758

Winder, M., Reuter, J. E., and Schladow, S. G. (2009). Lake warming favours smallsized planktonic diatom species. Proc. R. Soc. B Biol. Sci. 276, 427-435. doi: 10.1098/rspb.2008.1200

Winslow, L. A., Read, J. S., Hansen, G. J. A., and Hanson, P. C. (2015). Small lakes show muted climate change signal in deepwater temperatures. Geophys. Res. Lett. 42, 355-361. doi: 10.1002/2014gl062325

Wolfe, A. P., Baron, J. S., and Cornett, R. J. (2001). Anthropogenic nitrogen deposition induces rapid ecological changes in alpine lakes of the Colororado Front Range (USA). J. Paleolimnol. 25, 1-7. doi: 10.1023/A:10081295 09322

Woodward, G., Perkins, D. M., and Brown, L. E. (2010). Climate change and freshwater ecosystems: impacts across multiple levels of organization. Philos. Trans. R. Soc. B Biol. Sci. 365, 2093-2106. doi: 10.1098/rstb. 2010.0055

Conflict of Interest Statement: The authors declare that the research was conducted in the absence of any commercial or financial relationships that could be construed as a potential conflict of interest.

Copyright (c) 2015 Perga, Frossard, Jenny, Alric, Arnaud, Berthon, Black, Domaizon, Giguet-Covex, Kirkham, Magny, Manca, Marchetto, Millet, Paillès, Pignol, Poulenard, Reyss, Rimet, Sabatier, Savichtcheva, Sylvestre and Verneaux. This is an open-access article distributed under the terms of the Creative Commons Attribution License (CC BY). The use, distribution or reproduction in other forums is permitted, provided the original author(s) or licensor are credited and that the original publication in this journal is cited, in accordance with accepted academic practice. No use, distribution or reproduction is permitted which does not comply with these terms. 